\title{
Iminonitroso Diels-Alder Reactions for Efficient Derivatization and Functionalization of Complex Diene-containing Natural Products
}

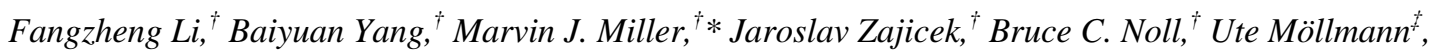
Hans-Martin Dahse $e^{\ddagger}$ and Patricia A. Miller ${ }^{\&}$

${ }^{\dagger}$ Department of Chemistry and Biochemistry and ${ }^{\circledR}$ Walther Cancer Research Center, University of Notre Dame, Notre Dame, Indiana 46556; ${ }^{\ddagger}$ Leibniz Institute for Natural Products Research and Infection Biolog - Hans Knoell Institute, Beutenbergstr. 11a, D-07745 Jena, Germany

mmiller1@nd.edu

\section{Supporting Information: Table of Content}

General experimental methods

Part I: Structure elucidation of cycloadduct 10, S1, 15 and 16

Part II: Antimicrobial activity and antiproliferative and cytotoxicity assays protocols of turimycin H3 cycloadducts

Part IV: Copies of ${ }^{1} \mathrm{H}$ and ${ }^{13} \mathrm{C}$ NMR spectra of new compounds and 2D-ROESY spectra of 11, 16 and 17

X-ray data of 14, 17, 18 and S1 (Submitted separately as cif files) 


\section{General Methods:}

Melting points were measured on a Thomas-Hoover capillary melting point apparatus and are uncorrected. Specific rotations were measured with a Rudolf Research Autopol III polarimeter at $589 \mathrm{~nm}$ and $20{ }^{\circ} \mathrm{C}$. All ${ }^{1} \mathrm{H}-$ and ${ }^{13} \mathrm{C}-\mathrm{NMR}$ experiments were performed at $25{ }^{\circ} \mathrm{C}$ using Varian UnityPlus and Bruker AVANCE spectrometers operating at the ${ }^{1} \mathrm{H}$ resonance frequency of $299.89,499.89,599.89$ and 800.13 MHz, respectively. Various 1D and 2D homo- and heteronuclear NMR techniques, ${ }^{1} \mathrm{H},{ }^{13} \mathrm{C}\left\{{ }^{1} \mathrm{H}\right\},{ }^{1} \mathrm{H}-{ }^{1} \mathrm{H}$ DQF-COSY, ${ }^{1} \mathrm{H}-{ }^{1} \mathrm{H}$ TOCSY, ${ }^{1} \mathrm{H}-{ }^{1} \mathrm{H}$ ROESY, ${ }^{1} \mathrm{H}-{ }^{13} \mathrm{C}$ gHMQC and ${ }^{1} \mathrm{H}_{-}{ }^{13} \mathrm{C}$ gHMBC, were employed to elucidate the structures of cycloadducts. The standard pulse sequences ${ }^{1-6}$ were used in these experiments.

Time domain data $\left(t_{2}\right.$ and $\left.t_{1}\right)$ for all $2 \mathrm{D}$ experiments were recorded as $2 \mathrm{kx} 1 \mathrm{k}$ complex matrices with 4 or 8 scans per $\mathrm{t}_{1}$ increment. The relaxation delay between individual scans was $1.2 \mathrm{sec}$. However, ROESY experiments (mixing time of $400 \mathrm{~ms}$ ) were performed with the relaxation delay of $4 \mathrm{~s}$. In homonuclear 2D experiments, zero filling was used in both $t_{2}$ and $t_{1}$ domains to obtain final $4 \mathrm{kx} 2 \mathrm{k}$ complex time domain data. In heteronuclear 2D experiments, linear prediction to the 2048 complex data points was applied in the $t_{1}$ domain, which were zero filled to 4096 to obtain final $2 \mathrm{kx} 4 \mathrm{k}$ complex time domain data. Shifted sine bell weighting functions were applied in both domains prior to double Fourier transformation.

Spectra measured with the Varian and Bruker spectrometers were processed using Varian VNMR 6.1C and Bruker TopSpin 1.3 software, respectively.

${ }^{1} \mathrm{H}$ and ${ }^{13} \mathrm{C}$ chemical shifts $(\delta)$, unless otherwise stated, are reported relative to residual solvent signal in the corresponding spectra; chloroform $7.26 \mathrm{ppm}$ and 77.23 ppm, methanol $3.31 \mathrm{ppm}$ and $49.00 \mathrm{ppm}$, tetrahydrofuran $3.58 \mathrm{ppm}$ and $25.37 \mathrm{ppm}$, methylene chloride $5.32 \mathrm{ppm}$ and $54.00 \mathrm{ppm}$.

Mass spectrometric analysis was performed on a JEOL AX505HA, JEOL JMS-GCmate or Micromass ZQ (LC/MS) mass spectrometer. Analytical TLC was carried out using Merck aluminum-backed $0.2 \mathrm{~mm}$ silica gel $60 \mathrm{~F}-254$ plates. Column chromatography was conducted using Merck silica gel 60 (230-400) meshes. All reactions were monitored by LC/MS.

X-ray diffraction analysis of single crystal was performed using a Bruker $\mathrm{x} 8$ ApexII diffractometer at the Molecular Structure Facility in the Department of Chemistry and Biochemistry of the University of Notre Dame. FTIR spectra were obtained using a Thermo-Nicolet IR200 spectrometer and absorption frequencies were reported in reciprocal centimeters $\left(\mathrm{cm}^{-1}\right)$.

The LC/MS analyses were carried out on a Waters ZQ instrument consisting of a chromatography module (Alliance HT), photodiode array detector (2996), and mass spectrometer (Micromass ZQ), using a 3 x $50 \mathrm{~mm}$ Pro C18 YMC reverse phase column (Waters, Milford, MA, www.waters.com). Mobile phases: $10 \mathrm{mM}$ ammonium acetate in HPLC grade water (A) and HPLC grade acetonitrile (B). A gradient was formed from $5 \%$ to $80 \%$ of $\mathrm{B}$ in 10 minutes at $0.7 \mathrm{~mL} / \mathrm{min}$. The MS electrospray 
source operated at a capillary voltage of $3.5 \mathrm{kV}$ and a desolvation temperature $300{ }^{\circ} \mathrm{C}$. All purchased reagents were of reagent grade quality and were used without further purification.

\section{Part I: Structure elucidation of cycloadduct 10, S1, 15 and 16.}

The structures of the cycloadducts were determined by analysis of $1 \mathrm{D}$ and $2 \mathrm{D}{ }^{1} \mathrm{H}$ and ${ }^{13} \mathrm{C}$ NMR spectra. Proton connectivities were derived by examination of the DQF-COSY and TOCSY spectra. Signals of all carbons with directly attached protons were assigned using gHMQC spectra. Finally, the gHMBC spectra were used to assign quaternary carbons and to check the correctness of the connectivities established by the interpretation of the other spectra. Stereochemistry of the cycloadducts was deduced from the ROESY spectra and magnitudes of the corresponding vicinal proton spin-spin coupling constants.

\section{Cycloadduct 10:}

${ }^{1} \mathrm{H}$ and ${ }^{13} \mathrm{C}$ NMR spectral data for cycloadduct $\mathbf{1 0}$ are summarized in Table S1. The vicinal coupling constants $J_{\mathrm{H} 12, \mathrm{H} 13}=1.71 \mathrm{~Hz}$ and $J_{\mathrm{H} 10, \mathrm{H} 11}=4.4 \mathrm{~Hz}$ suggested that the six-membered oxazo-ring adapts a conformation in which the H13 and H10 protons are at pseudo-axial and pseudo-equatorial positions, respectively, (Figure S1). Their corresponding chemical shifts of $\delta 4.66 \mathrm{ppm}$ and $5.25 \mathrm{ppm}$, and existence of a cross-peak between the P2 and H13 protons in the ROESY spectrum indicated the regiochemistry of $\mathbf{1 0}$ at the $\mathrm{C} 10$ and $\mathrm{C} 13$ carbon positions. Additionally, the ROESY spectrum showed strong cross-peaks between the $\mathrm{H} 10$ and $\mathrm{H} 19$ proton signals, and the $\mathrm{H} 13$ and $\mathrm{H} 16$ resonances, which suggested the stereochemistry and possible conformation of cycloadduct $\mathbf{1 0}$ as depicted in Figure S1. The large vicinal proton coupling $J_{\mathrm{H} 9, \mathrm{H} 10}=7.9 \mathrm{~Hz}$ together with a strong NOE interaction between the $\mathrm{H} 10$ and $\mathrm{H} 19$ protons revealed a trans arrangement of the $\mathrm{H} 9$ and $\mathrm{H} 10$ protons with a dihedral angle of $\sim 140-160^{\circ}$. The Newman projections are drawn in Figure S1 along the C9$\mathrm{C} 8$ and $\mathrm{C} 14-\mathrm{C} 15$ bonds based on the corresponding vicinal coupling constants $\left(J_{\mathrm{H} 8, \mathrm{H} 9}=3.3 \mathrm{~Hz}, J_{\mathrm{H} 13, \mathrm{H} 14 \mathrm{a}}=7.0 \mathrm{~Hz}, J_{\mathrm{H} 13, \mathrm{H} 14 \mathrm{~b}}=2.8 \mathrm{~Hz}, J_{\mathrm{H} 15, \mathrm{H} 14 \mathrm{a}}=5.4 \mathrm{~Hz}, J_{\mathrm{H} 15, \mathrm{H} 14 \mathrm{~b}}=2.9 \mathrm{~Hz}\right)$. 
Table S1. ${ }^{1} \mathrm{H}$ and ${ }^{13} \mathrm{C}$ NMR spectral data for cycloadduct $\mathbf{1 0}$.

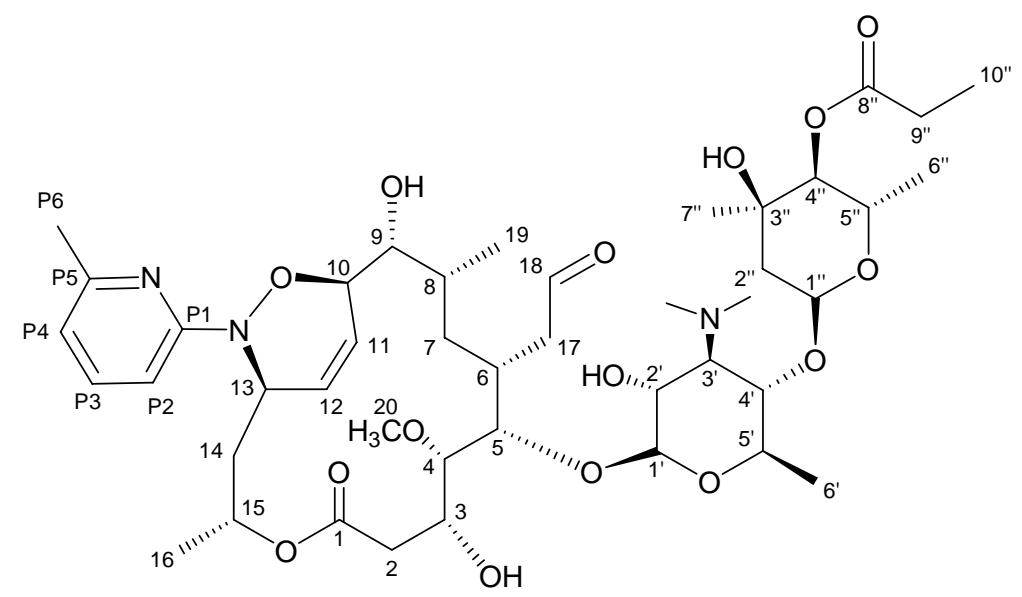

\begin{tabular}{|c|c|c|}
\hline Carbon no. & $\begin{array}{l}{ }^{1} \mathrm{H}\left(\mathrm{CD}_{2} \mathrm{Cl}_{2}, 600 \mathrm{MHz}\right) \\
\delta[\mathrm{ppm}](\text { mult, } J[\mathrm{~Hz}])\end{array}$ & $\begin{array}{c}{ }^{13} \mathrm{C}\left(\mathrm{CD}_{2} \mathrm{Cl}_{2}, 75 \mathrm{MHz}\right) \\
\delta[\mathrm{ppm}]\end{array}$ \\
\hline 1 & & 172.4 \\
\hline 2 & a. $2.58(\mathrm{dd}, 6.2,14.7) ;$ b. $2.62(\mathrm{dd}, 6.2,14.7)$ & 40.9 \\
\hline 3 & $4.20(\mathrm{~m})$ & 69.0 \\
\hline 4 & $3.11(\mathrm{dd}, 1.7,8.0)$ & 84.5 \\
\hline 5 & $3.75(\mathrm{dd}, 1.7,8.3)$ & 81.4 \\
\hline 6 & $2.20(\mathrm{~m})$ & 33.2 \\
\hline 7 & a. $0.90(\mathrm{~m}) ;$ b $1.77(\mathrm{ddd}, 3.4,9.7,14.4)$ & 32.9 \\
\hline 8 & $1.63(\mathrm{~m})$ & 38.5 \\
\hline 9 & $3.90(\mathrm{dd}, 3.3,7.9)$ & 74.3 \\
\hline 10 & $5.25(\mathrm{~m})$ & 54.0 \\
\hline 11 & $6.22(\mathrm{ddd}, 2.3,4.4,10.4)$ & 128.0 \\
\hline 12 & $5.76(\mathrm{dt}, 1.71,10.4)$ & 128.4 \\
\hline 13 & $4.66(\mathrm{~m})$ & 69.7 \\
\hline \multirow[t]{2}{*}{14} & a. $1.95(\mathrm{ddd}, 2.8,5.4,15.9)$ & 38.4 \\
\hline & b. $2.08(\mathrm{ddd}, 2.9,6.9,15.9)$ & \\
\hline 15 & $5.26(\mathrm{~m})$ & 67.9 \\
\hline 16 & $1.31(3 \mathrm{H}, \mathrm{d}, 6.6)$, & 20.6 \\
\hline 17 & a. $2.42(\mathrm{~m}) ;$ b. $2.90(\mathrm{ddd}, 0.9,8.9,18.5)$ & 46.4 \\
\hline 18 & $9.76(\mathrm{t}, 0.9)$ & 203.8 \\
\hline 19 & $1.11(3 \mathrm{H}, \mathrm{d}, 7.1)$ & 17.1 \\
\hline 20 & $3.44(3 \mathrm{H}, \mathrm{s})$ & 61.7 \\
\hline 1 ' & $4.25(\mathrm{~d}, 7.6)$ & 105.3 \\
\hline $2^{\prime}$ & $3.44(\mathrm{dd}, 7.6,10.0)$ & 71.7 \\
\hline $3^{\prime}$ & $2.40(\mathrm{~m})$ & 69.3 \\
\hline 4 & $3.21(\mathrm{t}, 9.4)$ & 76.3 \\
\hline 5 & $3.28(\mathrm{~m})$ & 73.6 \\
\hline $6{ }^{\prime}$ & $1.22(3 \mathrm{H}, \mathrm{d}, 6.1)$ & 19.4 \\
\hline $3^{\prime}-\mathrm{N}\left(\mathrm{CH}_{3}\right)_{2}$ & $2.44(6 \mathrm{H}$, br s $)$ & 42.3 \\
\hline 1, & $5.04(\mathrm{~d}, 3.8)$ & 97.6 \\
\hline $2, '$ & a. $1.81(\mathrm{dd}, 3.8,14.27) ;$ b. $1.95(\mathrm{bd}, 14.27)$ & 42.3 \\
\hline
\end{tabular}




\begin{tabular}{|l|l|l|}
\hline $3^{\prime}$ & & 69.7 \\
\hline $4^{\prime}$ & $4.56(\mathrm{~d}, 10.13)$ & 77.8 \\
\hline $5^{\prime}$ & $4.41(\mathrm{~m})$ & 63.9 \\
\hline $6^{\prime}$ & $1.08(3 \mathrm{H}, \mathrm{d}, 6.22)$ & 25.7 \\
\hline $7^{\prime}$ & $1.04(3 \mathrm{H}, \mathrm{s})$ & 17.1 \\
\hline $8^{\prime}$ & & 174.7 \\
\hline $9^{\prime}$ & $2.41(2 \mathrm{H}, \mathrm{m})$ & 28.1 \\
\hline $10^{\prime}$ & $1.15(3 \mathrm{H}, \mathrm{t}, 7.6)$ & 9.65 \\
\hline P1 & & 158.5 \\
\hline P2 & $6.87(\mathrm{~d}, 8.3)$ & 105.7 \\
\hline P3 & $7.49($ overlap, dd, 7.3, 8.3) & 138.8 \\
\hline P4 & $6.61(\mathrm{~d}, 7.3)$ & 115.1 \\
\hline P5 & & 157.7 \\
\hline P6 & $2.38(3 \mathrm{H}, \mathrm{s})$ & 24.6 \\
\hline
\end{tabular}

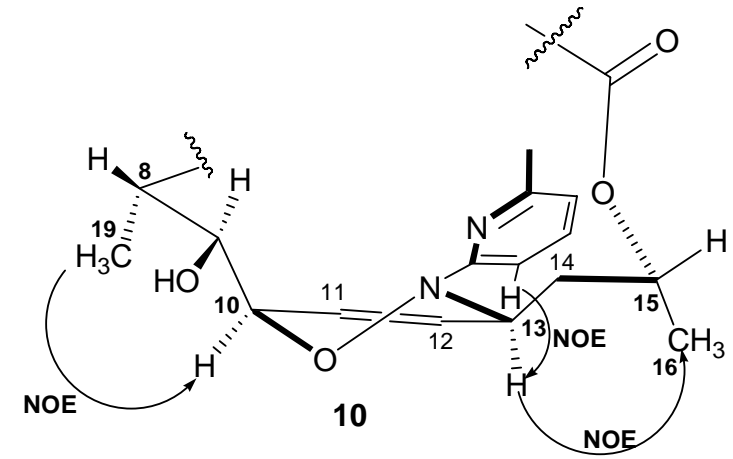

$\mathrm{J}_{12 \mathrm{H}, 13 \mathrm{H}}=1.71 \mathrm{~Hz} \longrightarrow \theta(\mathrm{H}-\mathrm{C} 13-\mathrm{C} 12-\mathrm{H})=\sim 70-90^{\circ}$ 13H pseudo-axial

$\mathrm{J}_{10 \mathrm{H}, 11 \mathrm{H}}=4.4 \mathrm{~Hz} \longrightarrow \theta(\mathrm{H}-\mathrm{C} 10-\mathrm{C} 9-\mathrm{H})=-50-60^{\circ}$ $10 \mathrm{H}$ pseudo-equatorial

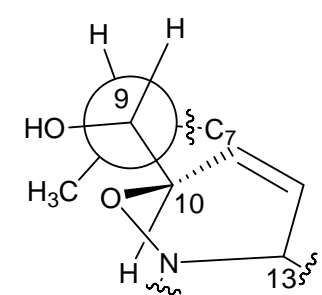

$\mathrm{J}_{9 \mathrm{H}, 8 \mathrm{H}}=3.3 \mathrm{~Hz} \quad \mathrm{~J}_{13 \mathrm{H}, 14 \mathrm{Ha}}=7.0 \mathrm{~Hz}, \mathrm{~J}_{13 \mathrm{H}, 14 \mathrm{Hb}}=2.8 \mathrm{~Hz}$ $\mathrm{J}_{9 \mathrm{H}, 10 \mathrm{H}}=7.9 \mathrm{~Hz} \quad \mathrm{~J}_{15 \mathrm{H}, 14 \mathrm{Ha}}=5.4 \mathrm{~Hz}, \mathrm{~J}_{15 \mathrm{H}, 14 \mathrm{Hb}}=2.9 \mathrm{~Hz}$ $\theta(\mathrm{H}-\mathrm{C} 10-\mathrm{C} 9-\mathrm{H}) \quad \theta(\mathrm{H}-\mathrm{C} 13-\mathrm{C} 14-\mathrm{Ha})=\sim 130-140^{\circ}$ $=\sim 140-160^{\circ}$

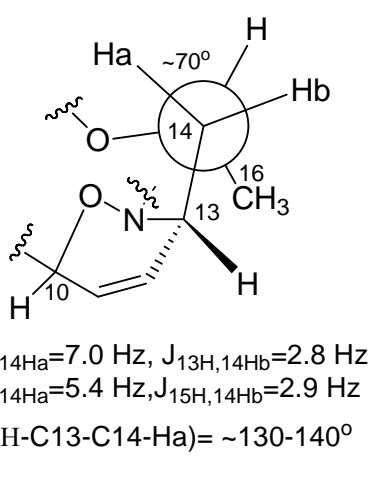

Figure S1. Selected NOE correlations and vicinal coupling constants relating to the regio- and stereo-chemistry of cycloadduct $\mathbf{1 0 .}$

\section{Cycloadduct (S1) between 5 and nitrosoisoxazole 13:}

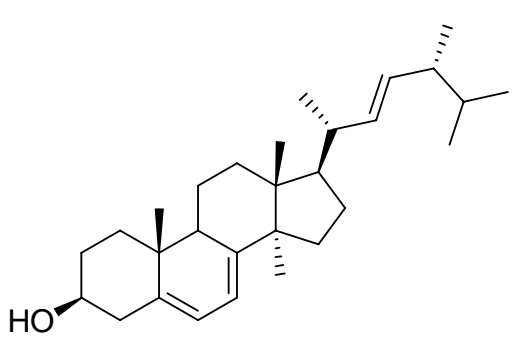

Ergosterol(5)

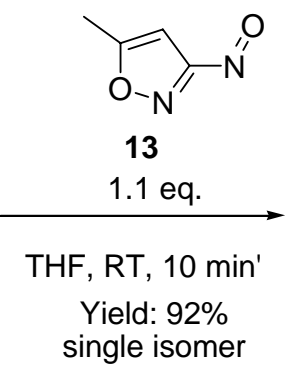

single isomer

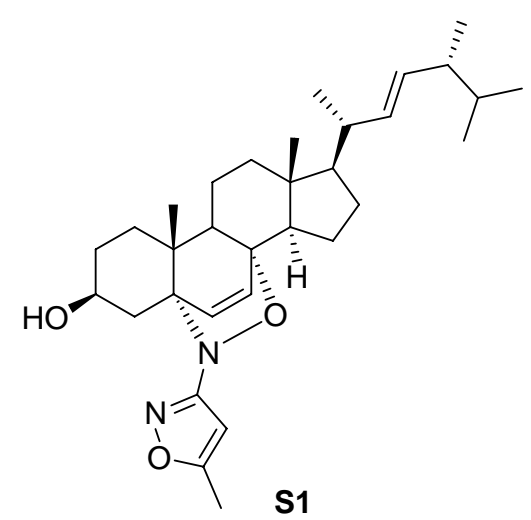

S1 


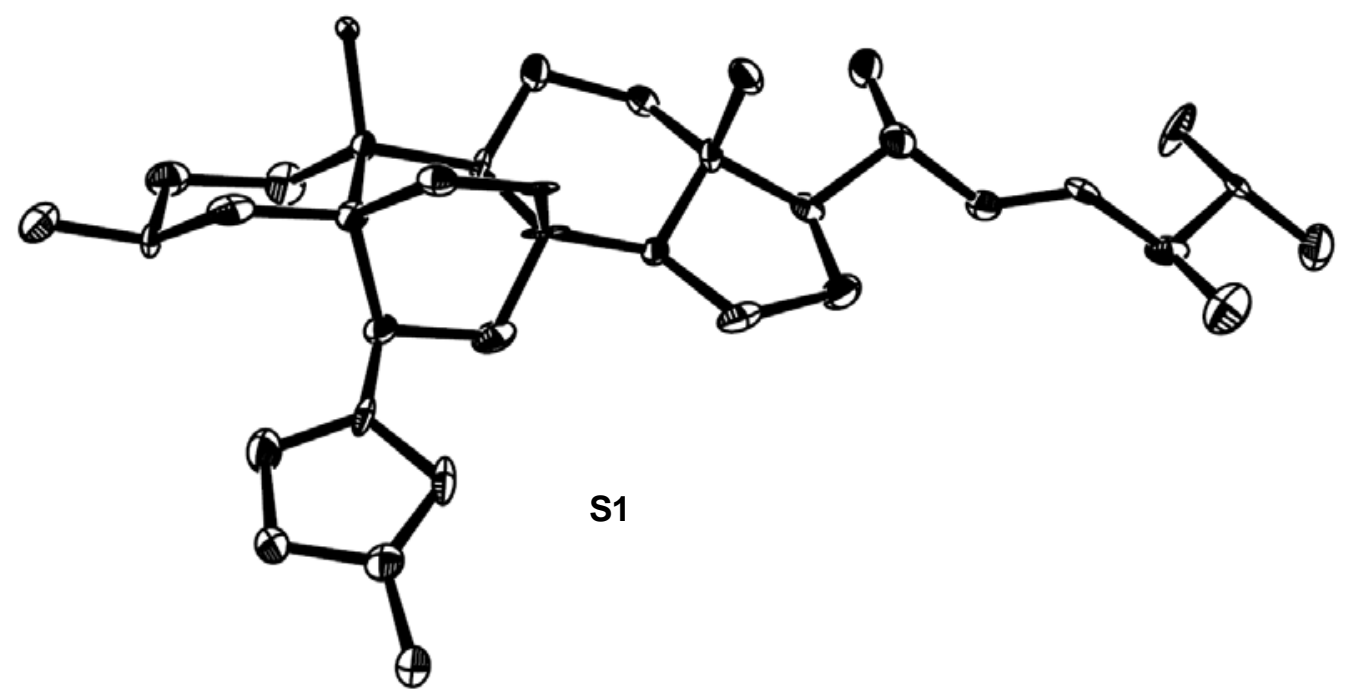

Figure S2. X-Ray structure of the cycloadduct (S1) between 5 and nitrosoisoxazole 13 (H omitted).

\section{Cycloadduct 15:}

${ }^{1} \mathrm{H}$ and ${ }^{13} \mathrm{C}$ NMR spectral data for cycloadduct 15 obtained by analyzing 1D ${ }^{1} \mathrm{H}$ and ${ }^{13} \mathrm{C}\left\{{ }^{1} \mathrm{H}\right\}$, and 2D DQF-COSY, gHMQC, gHMBC and ROESY spectra (600 or $800 \mathrm{MHz}, \mathrm{CD}_{2} \mathrm{Cl}_{2}$ ) are given in Table S2. Each 2D spectrum was measured within less than 4 hours using freshly prepared sample ( $\sim 90 \%$ purity) because the compound gradually decomposed in this solvent (3-4 hrs.). The regio- and stereo-chemistry of 15 was assigned mainly based on the relating NOE correlations as shown in Figure S3.

Cycloadduct 15 showed a better stability in $d_{8}$-THF $(6-8 \mathrm{hrs}$.) and measurements of the above NMR spectra revealed existence of tautomerization as shown in Scheme S1.

Table S2. ${ }^{1} \mathrm{H}$ and ${ }^{13} \mathrm{C}$ NMR spectral data of cycloadduct 15.

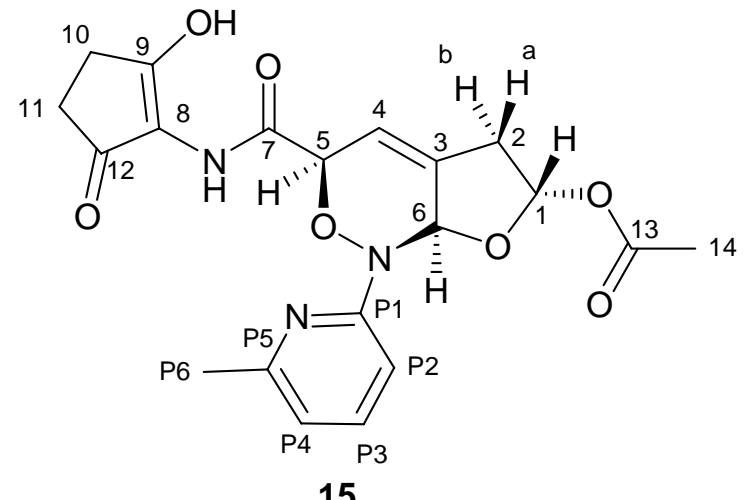




\begin{tabular}{|c|c|c|}
\hline $\begin{array}{c}\text { Carbon } \\
\text { no. }\end{array}$ & $\begin{array}{l}{ }^{1} \mathrm{H}\left(\mathrm{CD}_{2} \mathrm{Cl}_{2}, 600 \mathrm{MHz}\right) \\
\delta[\mathrm{ppm}](\mathrm{mult}, J[\mathrm{~Hz}])\end{array}$ & $\begin{array}{c}{ }^{13} \mathrm{C}\left(\mathrm{CD}_{2} \mathrm{Cl}_{2}, 150 \mathrm{MHz}\right) \\
\delta[\mathrm{ppm}]\end{array}$ \\
\hline 1 & $6.41(\mathrm{dd}, 3.7,6.1)$ & 97.2 \\
\hline 2 & $\begin{array}{l}\text { a. } 3.22 \text { (dddd, } 1.4,3.0,6.1,16.6) ; b . \\
2.81 \text { (dddd, } 1.1,3.7,6.3,16.6)\end{array}$ & 35.8 \\
\hline 3 & & 136.5 \\
\hline 4 & $6.16(\mathrm{~m})$ & 118.9 \\
\hline 5 & $5.03(\mathrm{~m})$ & 76.7 \\
\hline 6 & $5.62(\mathrm{~m})$ & 86.5 \\
\hline 7 & & 170.3 \\
\hline 8 & & 115.2 \\
\hline 9 & & 171.2 \\
\hline 10 & $2.51(2 \mathrm{H}, \mathrm{br}, \mathrm{s})$ & 24.4 \\
\hline 11 & $2.51(2 \mathrm{H}, \mathrm{br}, \mathrm{s})$ & 24.4 \\
\hline 12 & & 171.2 \\
\hline 13 & & 170.3 \\
\hline 14 & $2.11(3 \mathrm{H}, \mathrm{s})$ & 21.5 \\
\hline $\mathrm{NH}$ & $10.3(\mathrm{~s})$ & \\
\hline $\mathrm{P} 1$ & & 159.6 \\
\hline $\mathrm{P} 2$ & $7.12(\mathrm{~d}, 8.1)$ & 109.6 \\
\hline P3 & 7.52 (overlap, dd, $7.6,8.1$ ) & 139.0 \\
\hline $\mathrm{P} 4$ & $7.00(\mathrm{~d}, 7.6)$ & 121.2 \\
\hline P5 & & 158.1 \\
\hline P6 & $2.61(3 \mathrm{H}, \mathrm{s})$ & 24.4 \\
\hline
\end{tabular}

Scheme S1. Tautomerization of 15.

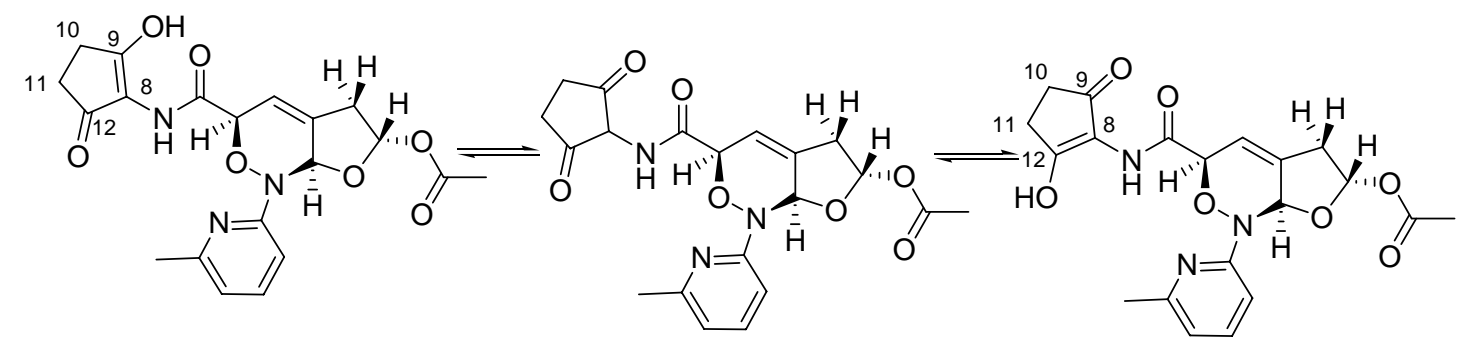




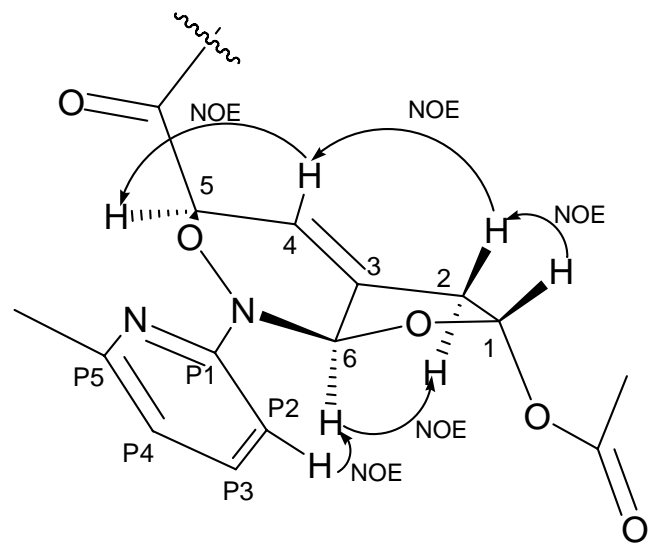

Figure S3. Selected NOE correlations relating the regio- and stereochemistry of $\mathbf{1 5}$

\section{Cycloadduct 16}

Similarly as in the previous case, the regio- and stereo-chemistry of $\mathbf{1 6}$ were determined from NOE correlations in the ROESY experiment (Figure S4). ${ }^{1} \mathrm{H}$ and ${ }^{13} \mathrm{C}$ NMR data of the cycloadduct $\mathbf{1 6}$ are shown in Table S3. The coupling constants $J_{\mathrm{H} 9, \mathrm{H} 10}=1.5 \mathrm{~Hz}$ and $J_{\mathrm{H} 11, \mathrm{H} 12}=3.8 \mathrm{~Hz}$ suggest that the six-membered oxazo-ring adapts a conformation in which $\mathrm{H} 9(\delta 4.26 \mathrm{ppm})$ is at a pseudo-axial position and $\mathrm{H} 12(\delta 5.12$ $\mathrm{ppm}$ ) is at a pseudo-equatorial (Figure $\mathrm{S} 4$ ).

Table S3. ${ }^{1} \mathrm{H}$ and ${ }^{13} \mathrm{C}$ NMR data of cycloadduct 16

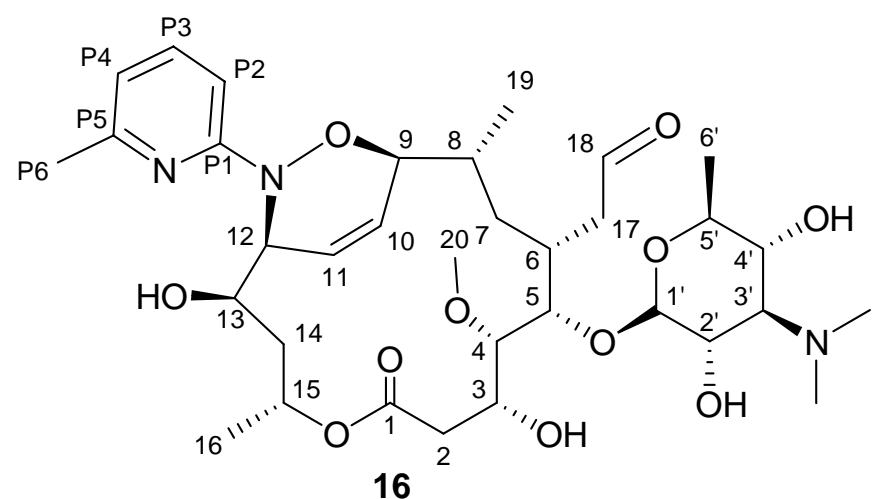

\begin{tabular}{|c|c|c|}
\hline $\begin{array}{c}\text { Carbon } \\
\text { no. }\end{array}$ & $\begin{array}{l}{ }^{1} \mathrm{H}\left(\mathrm{CD}_{2} \mathrm{Cl}_{2}, 600 \mathrm{MHz}\right) \\
\delta[\mathrm{ppm}](\text { mult, } J[\mathrm{~Hz}])\end{array}$ & $\begin{array}{c}{ }^{13} \mathrm{C}\left(\mathrm{CD}_{2} \mathrm{Cl}_{2}, 150 \mathrm{MHz}\right) \\
\delta[\mathrm{ppm}]\end{array}$ \\
\hline 1 & & 169.8 \\
\hline 2 & $\begin{array}{l}\text { a. } 2.59(\mathrm{dd}, 5.0,12.8) ; \text { b. } 2.64 \\
(\mathrm{dd}, 10.3,12.8)\end{array}$ & 40.9 \\
\hline 3 & $4.06(\mathrm{~m})$ & 71.7 \\
\hline
\end{tabular}




\begin{tabular}{|l|l|l|}
\hline 4 & $3.42(\mathrm{~m})$ & 80.4 \\
\hline 5 & $3.77(\mathrm{t}, 3.8)$ & 84.8 \\
\hline 6 & $2.54(\mathrm{~m})$ & 36.0 \\
\hline 7 & $\begin{array}{l}\text { a. } 0.99(\mathrm{ddd}, 6.7,10.3,14.0) ; \mathrm{b} \\
1.58(\mathrm{dd}, 7.6,14.0)\end{array}$ & 31.7 \\
\hline 8 & $1.93(\mathrm{~m})$ & 34.7 \\
\hline 9 & $4.26(\mathrm{br} \mathrm{s})$ & 77.0 \\
\hline 10 & $5.90(\mathrm{dt}, 1.5,10.6)$ & 125.9 \\
\hline 11 & $6.05(\mathrm{ddd}, 2.1,3.8,10.6)$ & 126.7 \\
\hline 12 & $5.12(\mathrm{br} \mathrm{s})$ & 58.8 \\
\hline 13 & $4.02(\mathrm{ddd}, 3.8,5.0,9.4)$ & 70.9 \\
\hline 14 & $\begin{array}{l}\text { a. } 1.63(\mathrm{ddd}, 3.6,8.1,13.0) ; \mathrm{b} . \\
\end{array}$ & 40.2 \\
\hline 15 & $2.14(\mathrm{ddd}, 5.2,10.0,13.4)$ & \\
\hline 16 & $5.17(\mathrm{~m})$ & 70.7 \\
\hline 17 & a. 2.94(m); b.2.35 (m) & 19.2 \\
\hline 18 & $9.72(\mathrm{br}, \mathrm{s})$ & 45.9 \\
\hline 19 & $1.07(3 \mathrm{H}, \mathrm{d}, 7.5)$ & 203.3 \\
\hline 20 & $3.61(3 \mathrm{H}, \mathrm{s})$ & 17.3 \\
\hline 1 & $4.44(\mathrm{~d}, 7.3)$ & 61.9 \\
\hline $2^{\prime}$ & $3.56(\mathrm{~m})$ & 105.8 \\
\hline $3^{\prime}$ & $3.08(\mathrm{~m})$ & 69.4 \\
\hline $4^{\prime}$ & $3.41(\mathrm{~m})$ & 74.2 \\
\hline $55^{\prime}$ & $3.46(\mathrm{~m})$ & 69.4 \\
\hline 6 & $1.33(3 \mathrm{H}, \mathrm{d}, 6.0)$ & 73.4 \\
\hline $3^{\prime}-\mathrm{N}\left(\mathrm{CH}_{3}\right)$ & $2.94(6 \mathrm{H}, \mathrm{br} \mathrm{s})$ & 18.2 \\
\hline P1 & & 46.3 \\
\hline P2 & $6.83(\mathrm{~d}, 8.1)$ & 159.2 \\
\hline P3 & $7.51(\mathrm{overlap}, \mathrm{dd}, 7.3,8.1)$ & 106.1 \\
\hline P4 & $6.63(\mathrm{~d}, 7.3)$ & 139.1 \\
\hline P5 & & 115.4 \\
\hline P6 & $2.38(3 \mathrm{H}, \mathrm{s})$ & 157.1 \\
\hline & & 24.4 \\
\hline
\end{tabular}




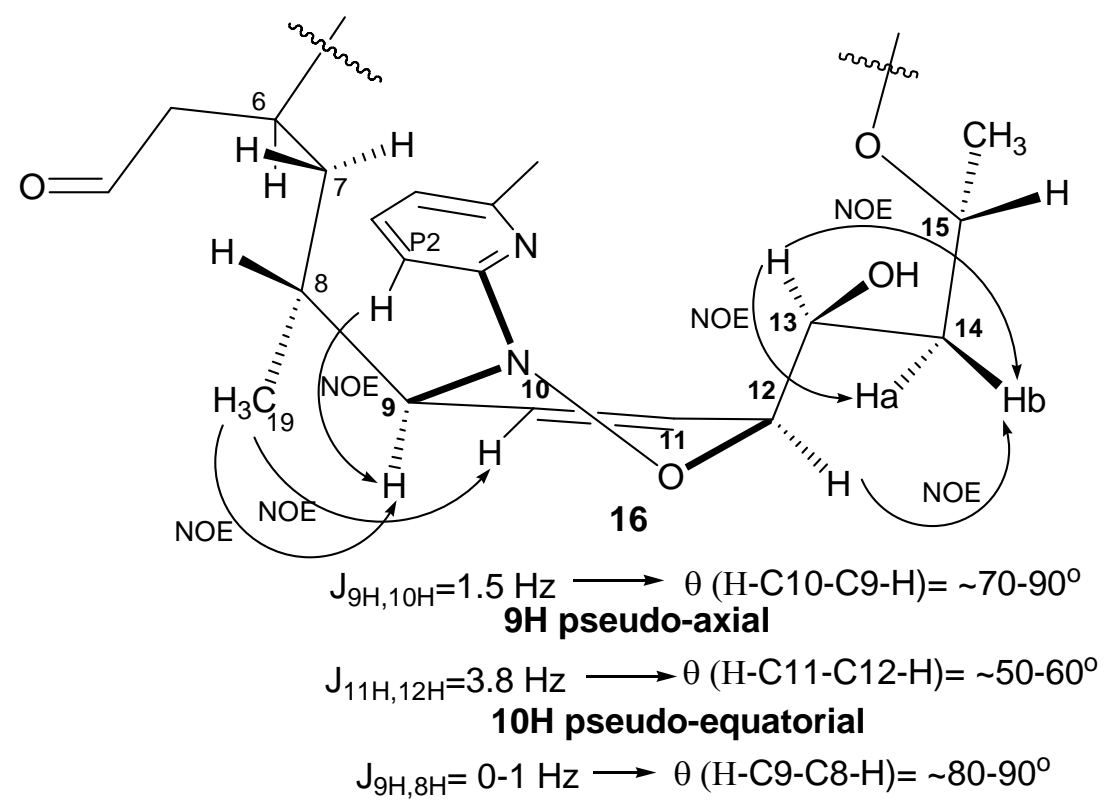

Figure S4. Selected NOE correlations and coupling constants relating the regio- and stereochemistry of cycloadduct $\mathbf{1 6}$

\section{References:}

1. Bodenhausen G., Freeman R., Niedermeyer R., Turner D. L., (1977), J. Magn. Reson. 26, 133-164.

2. Griesinger C., Otting G., Wuthrich K., Ernst R. R., (1988), J. Am. Chem. Soc. 110, 7870-7872.

3. Bax A., Morris G. A., (1981), J. Magn. Reson. 42, 501-505.

4. Bax A., Griffey R. H., Hawkins B. L., (1983) J. Magn. Reson. 55, 301-315.

5. Wijmenga S. S., Hallenga K., Hilbers C. W., (1989), J. Magn. Reson. 84, 634642.

6. Bax A., Summers M. F., (1986), J. Am. Chem. Soc. 108, 2093-2094. 
Part II: Antimicrobial activity and antiproliferative and cytotoxicity assays protocols of turimycin $\mathrm{H} 3$ cycloadducts.

\section{Antimicrobial activity of turimycin cycloadducts in the agar diffusion assay. ${ }^{a}$}

\begin{tabular}{|c|c|c|c|c|c|c|c|c|c|c|c|c|}
\hline \multirow[t]{3}{*}{ Compound $\mathrm{Nr}$} & \multirow[t]{3}{*}{ Solvent } & \multicolumn{5}{|c|}{ Gram-positive bacteria } & \multicolumn{3}{|c|}{$\begin{array}{c}\text { Gram-negative } \\
\text { bacteria }\end{array}$} & \multicolumn{2}{|c|}{ Yeast } & \multirow{2}{*}{$\begin{array}{c}\text { Fungus } \\
\begin{array}{c}\mathrm{P} . \\
\text { notatum }\end{array} \\
\end{array}$} \\
\hline & & \begin{tabular}{|c|} 
B. \\
subtilis
\end{tabular} & & $\begin{array}{l}\text { S. } \\
\text { ureus }\end{array}$ & $\begin{array}{c}\text { E. } \\
\text { faecalis }\end{array}$ & $\begin{array}{c}\text { M. } \\
\text { vaccae }\end{array}$ & $\begin{array}{c}\text { E. } \\
\text { coli }\end{array}$ & aeru & sinosa & $\begin{array}{c}\text { S. } \\
\text { salmonicolor } \\
\end{array}$ & $\begin{array}{c}\mathrm{C} . \\
\text { albicans } \\
\end{array}$ & \\
\hline & & $\begin{array}{c}\text { ATCC } \\
6633 \\
\end{array}$ & \begin{tabular}{l|} 
SG \\
511 \\
\end{tabular} & $\begin{array}{l}134 / 93 \\
\text { MRSA } \\
\end{array}$ & \begin{tabular}{|l|}
1528 \\
VRE \\
\end{tabular} & 10670 & $\begin{array}{l}\mathrm{SG} \\
458 \\
\end{array}$ & $\begin{array}{l}\mathrm{SG} \\
137 \\
\end{array}$ & $\begin{array}{c}\text { K799, } \\
61 \\
\end{array}$ & 549 & $\begin{array}{c}\text { BMSY } \\
212 \\
\end{array}$ & "JP36 \\
\hline $\begin{array}{c}\text { 4(Turimycin } \\
\text { H3) } \\
\end{array}$ & $\begin{array}{c}\mathrm{DMSO} / \\
\mathrm{MeOH} \\
\end{array}$ & 29 & 30 & 10 & 16.5 & 40 & 19 & 11 & 21.5 & 0 & 0 & 0 \\
\hline 19 & DMSO & 28 & 29 & 19P & 15 & 32 & $14 p$ & 0 & 0 & 0 & 0 & 0 \\
\hline 10 & $\begin{array}{c}\mathrm{DMSO} / \\
\mathrm{MeOH} \\
\end{array}$ & 26.5 & 27.5 & 0 & $18 p$ & 30 & 0 & 0 & $11 \mathrm{P}$ & 0 & 0 & 0 \\
\hline 20 & DMSO & 26 & 25 & 0 & 16 & 27 & 13 & 0 & $16 \mathrm{P}$ & 10 & 0 & 10.5 \\
\hline 21 & DMSO & $21 / 25 p$ & 24.4 & $14 \mathrm{P}$ & $13 / 17 p$ & $23 / 32 p$ & 15.5 & 0 & 0 & 0 & 0 & 0 \\
\hline $\begin{array}{c}\text { Ciprofloxacin } \\
5 \mu \mathrm{g} / \mathrm{ml}\end{array}$ & $\begin{array}{c}\mathrm{DMSO} / \\
\mathrm{MeOH}\end{array}$ & 28 & 17.5 & 0 & 16 & 18 & 20 & 24 & 17 & - & - & - \\
\hline $\begin{array}{c}\text { Amphotericin } \\
\text { B } \\
10 \mu \mathrm{g} / \mathrm{ml} \\
\end{array}$ & $\begin{array}{l}\mathrm{DMSO} / \\
\mathrm{MeOH}\end{array}$ & - & - & - & - & - & - & - & - & $18 p$ & 20 & $16 \mathrm{p}$ \\
\hline $\begin{array}{c}\mathrm{DMSO} / \\
\mathrm{MeOH}\end{array}$ & & $13 \mathrm{P}$ & $13 \mathrm{P}$ & 0 & $13 \mathrm{P}$ & 0 & 0 & $12 \mathrm{P}$ & $22 \mathrm{P}$ & $18 \mathrm{P}$ & 0 & $13 \mathrm{P}$ \\
\hline
\end{tabular}

${ }^{a}$ Inhibition zones in mm; $50 \mu \mathrm{L}$ of $2 \mathrm{mM}$ solution were added to agar wells of $9 \mathrm{~mm}$ in diameter. $\mathrm{p}=$ colonies within the inhibition zone, $\mathrm{P}=$ many colonies within the inhibiton zone. literature. $^{7}$

Antibacterial activity was determined by agar diffusion tests according to

Test organisms were suspended in the melted agar medium and poured into petri dishes. Wholes of $9 \mathrm{~mm}$ in diameter were cutted in the agar and filled with 50 $\mu \mathrm{L}$ of a $2 \mathrm{mM}$ solution of the compounds. Inhibition zones were read after overnight incubation. The details of the method are described also in: Sergii Afonin, Ralf W. Glaser, Marina Berditchevskaja, Parvesh Wadhwani, Karl-Heinz Gührs, Ute Möllmann, Andrea Perner, and Anne S. Ulrich. 4-Fluoro-phenylglycine as a label for ${ }^{19}$ F-NMR structure analysis of membrane associated peptides. ChemBioChem 2003, 4, $1151-1163$

Bioassay protocols of antiproliferative and cytotoxicity assays:

\section{L-929, K-562 and HeLa assays (performed at HKI, Germany):}

\section{Cells and culture conditions}

Cells of established adherent cell lines L-929 (DSM ACC 2) (mouse fibroblasts) and suspended K-562 (DSM ACC 10) (human leukaemia cell line) were 
cultured in RPMI medium as described previously. ${ }^{9}$ The adherent cells of L-929 and HeLa (Human-Cervix-Carcinome cell line) were harvested at the logarithmic growth phase after trypsinization, using $0.25 \%$ trypsin in PBS containing $0.02 \%$ EDTA (Biochrom KG Kat.-Nr. L2163).

\section{Antiproliferative and cytotoxicity assays}

The target compounds were assayed against cell lines K-562 and L-929 for their antiproliferative effects $\left(\mathrm{GI}_{50}\right.$ : concentration which inhibited cell growth by $50 \%$ ), and against HeLa for their cytotoxic effects $\left(\mathrm{CC}_{50}\right.$ : Cytotoxic concentration which contains a specific destructive action on certain cells by $50 \%$; used particularly in referring to the lysis of cells). The cells were incubated with ten concentrations of the target compounds. The antiproliferative and cytotoxicity assays were described previously. $^{9}$

\section{Incubation conditions}

Cells of L-929, K-562, and HeLa were incubated for 72 hours at $37{ }^{\circ} \mathrm{C}$ in a humidified atmosphere and $5 \% \mathrm{CO}_{2}$.

\section{Methods of evaluation}

Suspension cultures of K-562 in microplates were analyzed by an electronic cell analyzer system CASY 1 (SCHÄRFE, Reutlingen, Germany) using an aperture of 150 $\mu \mathrm{m}$. The principles of measurement and evaluation of data were described (Glauner 1991). ${ }^{8}$ The $0.2 \mathrm{ml}$ content of each well in the microplate was diluted 1:50 with CASYTON (SCHÄRFE). Every count/ml was automatically calcucated from the arithmetic mean of three successive counts of $0.4 \mathrm{ml}$ each. From the dose response curves the $\mathrm{Gl}_{50}$ values were calculated with CASYSTAT. The $\mathrm{Gl}_{50}$ value was defined as being where the concentration-response curve intersected the $50 \%$ line, determined by means of the cell counts $/ \mathrm{ml}$, compared to control. The essential parameters for the estimation of growth inhibition and for changes in diameter distribution curves are expressed as diagrams.

The monolayer of the adherent L-929 and HeLa cells were fixed by glutaraldehyde and stained with a solution of methylene blue as described. ${ }^{9}$

After gently washing the stain was eluted by $0.2 \mathrm{ml}$ of $0.33 \mathrm{~N} \mathrm{HCl}$ in the wells. The optical densities were measured at $660 \mathrm{~nm}$ in a DYNATECH MR 7000 microplate reader. Comparisons of the different values were performed with Microsoft EXCEL.

\section{MCF7 cells and PC3 assays (performed at UND, USA):}

MCF7 cells and PC3 cells are both adherent cell lines for the assay. Cells are added to 96 well microplate and incubated at $37^{\circ} \mathrm{C}$ and $5 \% \mathrm{CO}_{2}$ for $24 \mathrm{~h}$ to allow the cells to adhere. They are then treated with $20 \mu \mathrm{M}$ concentration of each sample. After $72 \mathrm{~h}$ incubation with sample compound, the media is removed from the cells 
crystal violet, washed and air dried. The stain was eluted with solution of Triton-X100. Optical density was measured at $595 \mathrm{~nm}$. Compounds that had over $50 \%$ inhibition at $20 \mu \mathrm{M}$ were then assayed at 8 different concentrations to estimate an IC50 .

\section{References:}

(7) European Pharmacopoeia. $3^{\text {rd }}$ Edition, 1997, 13: 118.

(8) Glauner, B. Biotec, 1991, 5, 58-61.

(9) Dahse, H.-M.; Schlegel, B.; Gräfe, U. Pharmazie, 2001, 56, 489-491. 
Part III: Experimental procedures:

\section{Representative procedure for preparation of 2-nitrosopyridines ${ }^{10}$ :}

\section{6-methyl-2-nitrosopyridines (3a)}<smiles>Cc1cccc(N=O)n1</smiles>

To an ice cooled solution of 6-amino-picoline (10.8 g, $0.10 \mathrm{~mol})$ and dimethyl sulfide $(8.0 \mathrm{~mL}, 0.11 \mathrm{~mol})$ in $100 \mathrm{~mL}$ of $\mathrm{CH}_{2} \mathrm{Cl}_{2}$ was added dropwise, over a period of $1 \mathrm{~h}$, a solution of $\mathrm{N}$-chlorosuccimide $(13.3 \mathrm{~g}, 0.10 \mathrm{~mol})$ in $250 \mathrm{~mL}$ of $\mathrm{CH}_{2} \mathrm{Cl}_{2}$. After the addition was complete, the solution was stirred at $0^{\circ} \mathrm{C}$ for an hour and then for an additional hour at room temperature. A solution of sodium methoxide in methanol (9.52 $\mathrm{g}, 0.17 \mathrm{~mol}, 30 \mathrm{wt} \%$ in $33 \mathrm{~mL}$ of $\mathrm{CH}_{3} \mathrm{OH}$ ) was then added, the mixture stirred for $10 \mathrm{~min}, 100 \mathrm{~mL}$ of water was added, and stirring continued for $4 \mathrm{~h}$. The organic layer was separated, and the aqueous layer was extracted with $50 \mathrm{~mL}$ of $\mathrm{CH}_{2} \mathrm{Cl}_{2}$. The combined organic layers were washed with $50 \mathrm{~mL}$ of water, dried $\left(\mathrm{Na}_{2} \mathrm{SO}_{4}\right)$ and filtered. The filtrate was concentrated under reduced pressure and residue $(S, S-$ Dimethyl- $N$-(6-methyl-2-pyridyl) sulfilimine) was used for the next reaction without further purification.

To an iced cooled solution of $m$-chloroperbenzoic acid $(78 \%, 28.7 \mathrm{~g}, 0.13$ mol) in $200 \mathrm{~mL}$ of dry $\mathrm{CH}_{2} \mathrm{Cl}_{2}$ was added dropwise a solution of sulfilimine in 100 $\mathrm{mL}$ of $\mathrm{CH}_{2} \mathrm{Cl}_{2}$. The mixture was stirred at $0^{\circ} \mathrm{C}$ for $90 \mathrm{~min}$, dimethyl sulfide $(4.0 \mathrm{~mL}$, $0.055 \mathrm{~mol}$ ) added, and stirring continued for an additional $\mathrm{h}$ at room temperature. A saturated solution of sodium carbonate $(250 \mathrm{~mL})$ was added and the layers were separated. The green organic layer was washed with water and dried $\left(\mathrm{Na}_{2} \mathrm{SO}_{4}\right)$ and filtered. The filtrate was concentrated under reduced pressure and the residue was recrystallized from diethyl ether to give 6-methyl-2-nitrosopyridine (3a) as a light yellow solid (3.7 g, 30\% yield for 2 steps). $R_{f}=0.4$ (EtOAc/hexanes, 1:2); mp: 96-98 ${ }^{\circ} \mathrm{C}$; mixture of monomer and dimer FTIR (KBr) $v_{\max } 3086,1600,1556,1459,1392$, 1370, 1280, 1215, 1025, 987, $790 \mathrm{~cm}^{-1} ;{ }^{1} \mathrm{H} \mathrm{NMR} \mathrm{(500} \mathrm{MHz}, \mathrm{CDCl}_{3}$ ): monomer $\delta 7.97\left(\mathrm{dd}, J_{1}=7.5 \mathrm{~Hz}, J_{2}=8.0 \mathrm{~Hz}, 1 \mathrm{H}\right), 7.55(\mathrm{~d}, J=7.5 \mathrm{~Hz}, 1 \mathrm{H}), 7.29$ ( d, $J=8.0$ $\mathrm{Hz}), 2.76(\mathrm{~s}, 3 \mathrm{H})$; dimer $\delta 7.78\left(\mathrm{dd}, J_{1}=7.8 \mathrm{~Hz}, J_{2}=8.0 \mathrm{~Hz}, 1 \mathrm{H}\right), 7.62(\mathrm{~d}, J=8.0 \mathrm{~Hz}$, $1 \mathrm{H}), 7.15(\mathrm{~d}, J=7.5 \mathrm{~Hz}, 1 \mathrm{H}), 2.16(\mathrm{~s}, 3 \mathrm{H})$; mixture of monomer and dimer ${ }^{13} \mathrm{C}$ NMR $\left(125 \mathrm{MHz}, \mathrm{CDCl}_{3}\right) \delta 169.2,159.0,156.9,155.2,139.4,139.3,129.6,125.0,115.8$, 109.5, 24.5, 23.6; FAB MS: monomer $123[\mathrm{M}+1]^{+}$; dimer $245[\mathrm{M}+1]^{+}$. 


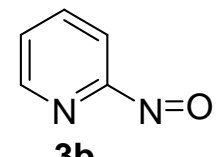

3b

Obtained as a yellowish solid. (30\% yield, $R_{f}=0.2$ (EtOAc/hexanes, 1:2); mp: 114-116 ${ }^{\circ} \mathrm{C}$; mixture of monomer and dimer FTIR (KBr) $v_{\max } 3075,1589,1561,1457,1430$, 1383, 1296, 1220, 1089, 959, $790 \mathrm{~cm}^{-1} ;{ }^{1} \mathrm{H} \mathrm{NMR}$ (500 $\mathrm{MHz}, \mathrm{CDCl}_{3}$ ): monomer $\delta 8.80(\mathrm{~d}, J=3.5 \mathrm{~Hz}, 1 \mathrm{H}), 8.08(\mathrm{~m}, 1 \mathrm{H}), 7.68\left(\mathrm{dd}, J_{1}=5.0 \mathrm{~Hz}, J_{2}=7.0 \mathrm{~Hz}\right), 7.39(\mathrm{~d}$, $J=8.0 \mathrm{~Hz}, 1 \mathrm{H})$; dimer $\delta 8.03\left(\mathrm{dd}, J_{1}=1 \mathrm{~Hz}, J_{2}=5 \mathrm{~Hz}, 1 \mathrm{H}\right), 7.93(\mathrm{~m}, 1 \mathrm{H}), 7.84(\mathrm{~d}, J$ $=8.0,1 \mathrm{H}), 7.31(\mathrm{~m} 1 \mathrm{H})$; mixture of monomer and dimer ${ }^{13} \mathrm{C}$ NMR $(125 \mathrm{MHz}$, $\left.\mathrm{CDCl}_{3}\right) \delta 155.8,149.4,147.2,139.6,129.7,125.8,115.9,111.3$; FAB MS: monomer $109[\mathrm{M}+1]^{+}$; dimer $217[\mathrm{M}+1]^{+}$.

5-Chloro-2-nitrosopyridine (11)<smiles>O=Nc1ccc(Cl)cn1</smiles>

Obtained as a yellowish solid. (20\% yield, $R_{f} 0.7$ EtOAc/hexanes, 1:2); mp: 126-128 ${ }^{\circ} \mathrm{C}$; mixture of monomer and dimer FTIR (KBr) $v_{\max } 3081,1577,1442,1394,1281$, 1104, 959, $840 \mathrm{~cm}^{-1} ;{ }^{1} \mathrm{H} \mathrm{NMR}\left(500 \mathrm{MHz}, \mathrm{CDCl}_{3}\right)$ : monomer $\delta 8.76(\mathrm{~s}, 1 \mathrm{H}), 8.02(\mathrm{~d}$, $J=8.5 \mathrm{~Hz}), 7.84(\mathrm{~d}, J=8.5 \mathrm{~Hz})$; dimer $\delta 8.00(\mathrm{~s}, 1 \mathrm{H}), 7.93(\mathrm{~d}, J=8.0,1 \mathrm{H}), 7.28(\mathrm{~d}, J$ $=10 \mathrm{~Hz})$; mixture of monomer and dimer ${ }^{13} \mathrm{C} \mathrm{NMR}\left(125 \mathrm{MHz}, \mathrm{CDCl}_{3}\right) \delta 166.8$, $153.7,148.4,145.9,139.5,138.9,138.5,134.3,119.7,111.3$.

5-Iodo-2-nitrosopyridine (12)<smiles>O=Nc1ccc(I)cn1</smiles>

12

Obtained as a yellowish solid. (25\% yield, $R_{f}=0.7$ EtOAc/hexanes, 1:2); mp: 124$126^{\circ} \mathrm{C}$; mixture of monomer and dimer FTIR (KBr) 3086, 1557, 1390, 1349, 1289 , 1093, 1001, 964, $847 \mathrm{~cm}^{-1} ;{ }^{1} \mathrm{H}$ NMR $\left(500 \mathrm{MHz}, \mathrm{CDCl}_{3}\right)$ : monomer $\delta 9.04(\mathrm{~s}, 1 \mathrm{H})$, $8.44(\mathrm{~d}, J=6.5 \mathrm{~Hz}, 1 \mathrm{H}), 7.06(\mathrm{~d}, J=8.0 \mathrm{~Hz}, 1 \mathrm{H})$; dimer $\delta 8.26(\mathrm{~s}, 1 \mathrm{H}), 8.26(\mathrm{~d}, J=$ $8.0 \mathrm{~Hz}, 1 \mathrm{H}), 7.65(\mathrm{~d}, J=8.0 \mathrm{~Hz}, 1 \mathrm{H}) ;{ }^{13} \mathrm{C} \mathrm{NMR}\left(125 \mathrm{MHz}, \mathrm{CDCl}_{3}\right) \delta 167.4,155.5$, 154.9 , 153.1, 148.0, 147.9, 120.2, 111.5, 102.3, 95.3; FAB MS: monomer 235 $[\mathrm{M}+1]^{+} ; \operatorname{dimer} 269[\mathrm{M}+1]^{+}$. 
<smiles>Cc1cc(N=O)no1</smiles>

13

Obtained as a yellowish solid. (20\% yield, $R_{f} 0.7$ EtOAc/hexanes, $\left.1: 2\right)$; mp: $88-90{ }^{\circ} \mathrm{C}$; mixture of monomer and dimer FTIR (KBr) $v_{\max } 3184,1584,1453,1274,1035,939$, $784 \mathrm{~cm}^{-1} ;{ }^{1} \mathrm{H}$ NMR $\left(500 \mathrm{MHz}, \mathrm{CDCl}_{3}\right): \delta 5.40(\mathrm{~s}, 1 \mathrm{H}), 2.51(\mathrm{~s}, 3 \mathrm{H}) ;{ }^{13} \mathrm{C}$ NMR $(125$ $\left.\mathrm{MHz}, \mathrm{CDCl}_{3}\right) \delta 183.1,172.8,84.9,29.9,12.9$.

Representative procedure for the NDA reactions of turimycin H3 (4) with 2nitroso pyridines: Preparation of turimycin cycloadduct 10.

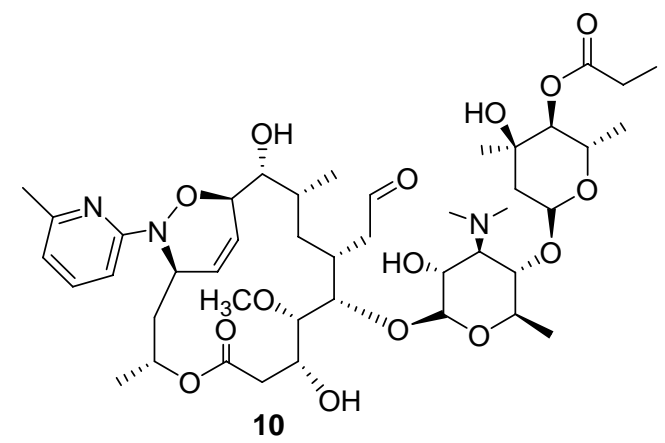

To a solution of 4 (30 mg, $0.0396 \mathrm{mmol})$ in $1 \mathrm{~mL}$ of $\mathrm{CH}_{2} \mathrm{Cl}_{2}$ or THF was added 6methyl-2-nitrosopyridine 3a (4.84 mg, $0.0396 \mathrm{mmol}, 1.0 \mathrm{eq}$ ) in $1 \mathrm{~mL}$ of $\mathrm{CH}_{2} \mathrm{Cl}_{2}$ at 0 ${ }^{\circ} \mathrm{C}$. The resulting reaction mixture was warmed to room temperature and then stirred for $30 \mathrm{~min}$. The solvent was removed under reduced pressure. ${ }^{1} \mathrm{H}$ NMR of the crude reaction mixture showed more than $90 \%$ conversion with $>90 \%$ purity of cycloadduct 10. Flash chromatography of the crude product on silica gel with $\mathrm{CH}_{2} \mathrm{Cl}_{2} / \mathrm{MeOH}$ (20:1 to $12: 1)$ afforded $10(31.4 \mathrm{mg}, 0.0356 \mathrm{mmol}, 90 \%)$ as a light yellow solid. (Since turimycin H3 10 and its cycoadduts have similar retention times on flash silica gel, in some cases, another 0.2 eq of 2-nitrosopyridines were added to completely convert turimycin 4 to their cycloadducts, which avoided the need to separate trace amounts of starting 4 from the cycloadducts.). mp 145-147 ${ }^{\circ} \mathrm{C} ;[\alpha]_{\mathrm{D}}{ }^{20}=-118.8(\mathrm{c}$ $=0.2, \mathrm{CHCl}_{3}$ ); IR 3421, 2936, 1722, 1578, 1451, 1274, 1164, 1056, 1029, 909, 784, $731 \mathrm{~cm}^{-1}$; Full NMR assignments see Table S1; HRMS [FAB, $\mathrm{MH}^{+}$] calcd for $\mathrm{C}_{44} \mathrm{H}_{70} \mathrm{~N}_{3} \mathrm{O}_{15} 880.4807$, found 880.4805. 


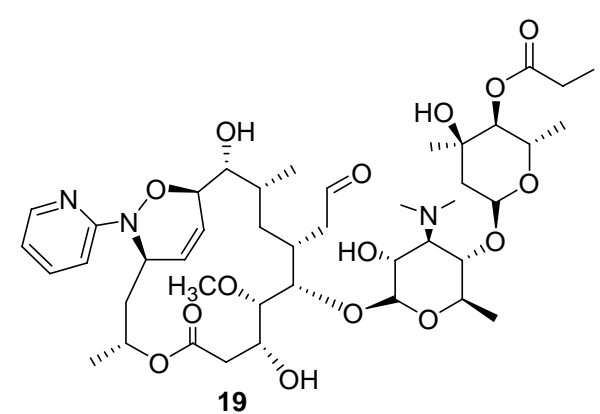

\section{Turimycin $\mathrm{H} 3$ cycloadduct 19}

Compound 19 was obtained as a light yellow solid in $91 \%$ yield. mp $134-136{ }^{\circ} \mathrm{C}$; $[\alpha]_{\mathrm{D}}{ }^{20}=-123.5\left(c=1.5, \mathrm{CHCl}_{3}\right)$; IR 3447, 2934, 1722, 1592, 1465, 1273, 1165, 1054, $1025,909,840,775 \mathrm{~cm}^{-1}$; ${ }^{1} \mathrm{H}$ NMR $\left(600 \mathrm{MHz}, \mathrm{CD}_{2} \mathrm{Cl}_{2}\right.$, the proton of $\mathrm{OH}$ was ommited) $\delta 9.76$ (br s, 1H), $8.20(\mathrm{~m}, 1 \mathrm{H}), 7.62$ (ddd, $J=1.8,7.2,8.4 \mathrm{~Hz}, 1 \mathrm{H}), 7.09$ (dt, $J=0.9,8.4 \mathrm{~Hz}, 1 \mathrm{H}), 6.76$ (ddd, $J=0.9,5.0,7.2 \mathrm{~Hz}, 1 \mathrm{H}), 6.23$ (ddd, $J=2.3,4.5$, $10.4 \mathrm{~Hz}, 1 \mathrm{H}), 5.75(\mathrm{dt}, J=1.5,10.4 \mathrm{~Hz}, 1 \mathrm{H}), 5.26(\mathrm{~m}, 1 \mathrm{H}), 5.21(\mathrm{~m}, 1 \mathrm{H}), 5.05$ ( br s, $1 \mathrm{H}), 4.65(\mathrm{~m}, 1 \mathrm{H}), 4.55(\mathrm{~d}, J=10.3 \mathrm{~Hz}, 1 \mathrm{H}), 4.40(\mathrm{~m}, 1 \mathrm{H}), 4.28(\mathrm{~d}, J=7.0 \mathrm{~Hz}, 1 \mathrm{H})$, $4.21(\mathrm{~m}, 1 \mathrm{H}), 3.91(\mathrm{dd}, J=3.3,7.9 \mathrm{~Hz}, 1 \mathrm{H}), 3.76(\mathrm{dd}, J=1.7,7.9 \mathrm{~Hz}, 1 \mathrm{H}), 3.45$ (s, $3 \mathrm{H}), 3.44$ (m, $1 \mathrm{H}), 3.29$ (m, $1 \mathrm{H}), 3.22(\mathrm{~m}, 1 \mathrm{H}), 3.12$ (dd, J=1.7, $7.8 \mathrm{~Hz}, 1 \mathrm{H}), 2.90$ (dd, $J=8.9,18.4 \mathrm{~Hz}, 1 \mathrm{H}), 2.63$ (dd, $J=6.2,14.7 \mathrm{~Hz}, 1 \mathrm{H}), 2.59$ (dd, $J=6.2,14.7 \mathrm{~Hz}, 1$ H), 2.55-2.34 (m, $10 \mathrm{H}), 2.21(\mathrm{~m}, 1 \mathrm{H}), 2.09$ (ddd, J=2.8, 7.1, $15.9 \mathrm{~Hz}, 1 \mathrm{H}), 1.97-$ $1.93(\mathrm{~m}, 2 \mathrm{H}), 1.81(\mathrm{dd}, J=4.0,14.4 \mathrm{~Hz}, 1 \mathrm{H}), 1.77$ (ddd, $J=3.2,9.5,14.4 \mathrm{~Hz}, 1 \mathrm{H})$, $1.63(\mathrm{~m}, 1 \mathrm{H}), 1.31(\mathrm{~d}, J=6.6 \mathrm{~Hz}, 3 \mathrm{H}), 1.23(\mathrm{~d}, J=6.0 \mathrm{~Hz}, 3 \mathrm{H}), 1.14$ (t, $J=7.6 \mathrm{~Hz}, 3$ H), 1.08 (br d overlap, $J=7.0 \mathrm{~Hz}, 6 \mathrm{H}$ ), 1.05 (s, $3 \mathrm{H}$ ), 0.90 (ddd, $J=3.0,10.2,14.4 \mathrm{~Hz}$, $1 \mathrm{H}) ;{ }^{13} \mathrm{C}$ NMR $\left(150 \mathrm{MHz}, \mathrm{CD}_{2} \mathrm{Cl}_{2}\right) \delta 203.8,174.7,172.3,159.1,148.6,138.5,128.3$, $127.9,116.0,109.2,105.1,97.5,84.5,81.2,77.7,76.2,74.2,73.5,72.0,69.8,69.7$, $69.3,69.0,68.0,63.9,61.7,53.8,46.2,42.2,40.9,38.6,38.3,33.2,32.9,30.2,28.0$, 25.7, 20.6, 19.3, 18.1, 17.1, 9.6; HRMS [FAB, $\mathrm{MH}^{+}$] calcd for $\mathrm{C}_{43} \mathrm{H}_{68} \mathrm{~N}_{3} \mathrm{O}_{15}$ 866.4650 , found 866.4627 .

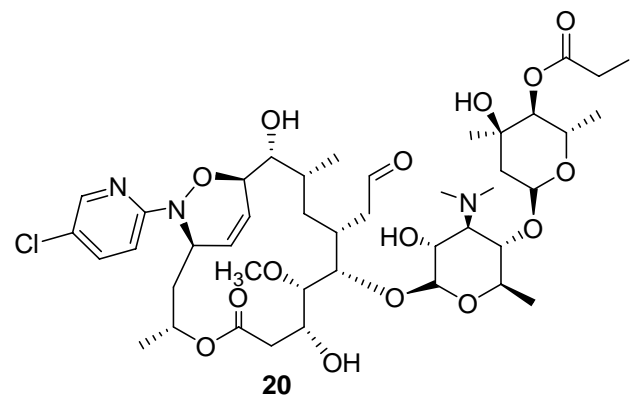

\section{Turimycin $\mathrm{H} 3$ cycloadduct 20}

Compound 20 was obtained as a light yellow solid in $88 \%$ yield. mp $156-158{ }^{\circ} \mathrm{C}$; $[\alpha]_{\mathrm{D}}{ }^{20}=-112.6\left(c=1.1, \mathrm{CHCl}_{3}\right)$; IR 3485, 2934, 1723, 1585, 1461, 1376, 1275, 1165 , $1059,1015,910,838,780 \mathrm{~cm}^{-1} ;{ }^{1} \mathrm{H}$ NMR $\left(600 \mathrm{MHz} \mathrm{CD}_{2} \mathrm{Cl}_{2}\right.$, the proton of $\mathrm{OH}$ was ommited) $\delta 9.76($ br s, $1 \mathrm{H}), 8.17(\mathrm{dd}, J=0.6,2.6 \mathrm{~Hz}, 1 \mathrm{H}), 7.59(\mathrm{dd}, J=2.6,8.9 \mathrm{~Hz}, 1$ H), 7.05 (dd, $J=0.6,8.9 \mathrm{~Hz}, 1 \mathrm{H}), 6.23(\mathrm{ddd}, J=2.3,4.5,10.5 \mathrm{~Hz}, 1 \mathrm{H}), 5.75$ (dt, $J=1.5,10.5 \mathrm{~Hz}, 1 \mathrm{H}), 5.26(\mathrm{~m}, 1 \mathrm{H}), 5.14(\mathrm{~m}, 1 \mathrm{H}), 5.05$ ( d, J=2.9 Hz, $1 \mathrm{H}), 4.64$ (m, $1 \mathrm{H}), 4.55(\mathrm{~d}, J=10.2 \mathrm{~Hz}, 1 \mathrm{H}), 4.41(\mathrm{~m}, 1 \mathrm{H}), 4.27$ (d, J=7.4 Hz, $1 \mathrm{H}), 4.20$ (m, $1 \mathrm{H})$, 
$3.91(\mathrm{dd}, J=3.2,8.2 \mathrm{~Hz}, 1 \mathrm{H}), 3.76(\mathrm{dd}, J=1.7,8.1 \mathrm{~Hz}, 1 \mathrm{H}), 3.46(\mathrm{~s}, 3 \mathrm{H}), 3.44(\mathrm{~m}, 1$ H), $3.28(\mathrm{~m}, 1 \mathrm{H}), 3.22$ (t, J=9.4 Hz,1 H), $3.10(\mathrm{dd}, J=1.8,8.1 \mathrm{~Hz}, 1 \mathrm{H}), 2.91(\mathrm{dd}$, $J=8.9,18.5 \mathrm{~Hz}, 1 \mathrm{H}), 2.63-2.57(\mathrm{~m}, 2 \mathrm{H}), 2.48-2.38(\mathrm{~m}, 10 \mathrm{H}), 2.21(\mathrm{~m}, 1 \mathrm{H}), 2.09$ (ddd, $J=2.8,7.2,15.9 \mathrm{~Hz}, 1 \mathrm{H}), 1.96-1.93(\mathrm{~m}, 2 \mathrm{H}), 1.81$ (dd, $J=4.0,14.4 \mathrm{~Hz}, 1 \mathrm{H})$, $1.72(\mathrm{~m}, 1 \mathrm{H}), 1.62(\mathrm{~m}, 1 \mathrm{H}), 1.31(\mathrm{~d}, J=6.6 \mathrm{~Hz}, 3 \mathrm{H}), 1.22(\mathrm{~d}, J=6.0 \mathrm{~Hz}, 3 \mathrm{H}), 1.14$ (t, $J=7.5 \mathrm{~Hz}, 3 \mathrm{H}), 1.08$ (d, J=6.2 Hz, $3 \mathrm{H}), 1.07$ (d, J=7.0 Hz, $3 \mathrm{H}), 1.04(\mathrm{~s}, 3 \mathrm{H}), 0.90$ $(\mathrm{m}, 1 \mathrm{H}) ;{ }^{13} \mathrm{C}$ NMR $\left(150 \mathrm{MHz}, \mathrm{CD}_{2} \mathrm{Cl}_{2}\right) \delta 203.8,174.7,172.3,157.5,147.0,138.4$, 128.1, 127.9, 123.0, 110.1, 105.1, 97.5, 84.6, 80.9, 77.7, 76.3, 73.8, 73.5, 72.0, 70.1, $69.7,69.3,68.9,67.9,63.9,61.7,53.7,46.1,42.2,40.9,38.7,38.2,33.2,33.0,30.2$, 28.0, 25.7, 20.5, 19.3, 18.1, 16.9, 9.6; HRMS [FAB, $\left.\mathrm{MH}^{+}\right]$calcd for $\mathrm{C}_{43} \mathrm{H}_{67} \mathrm{ClN}_{3} \mathrm{O}_{15}$ 900.4261, found 900.4224 .

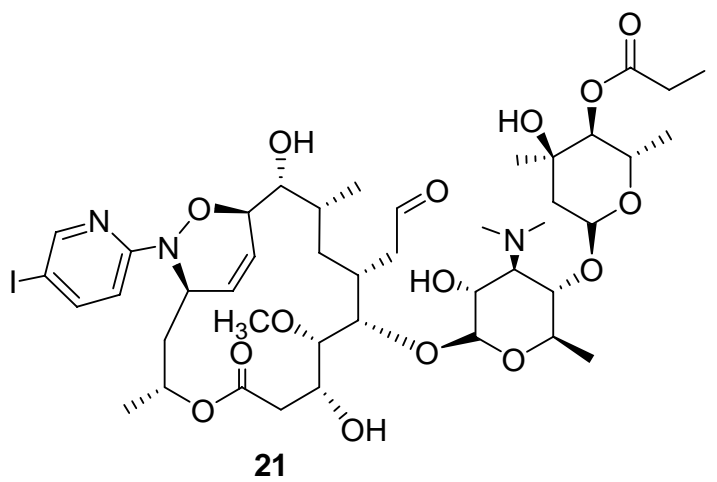

\section{Turimycin $\mathrm{H} 3$ cycloadduct 21}

Compound 21 was obtained as a light yellow solid in $89 \%$ yield. mp $164-166{ }^{\circ} \mathrm{C}$; $[\alpha]_{\mathrm{D}}^{20}=-112.0\left(c=0.5, \mathrm{CHCl}_{3}\right)$; IR $(\mathrm{KBr}): 3449,2936,1721,1574,1460,1399$, $1375,1168,1120,1081,1019,910,848 \mathrm{~cm}^{-1}$; ${ }^{1} \mathrm{H} \mathrm{NMR}\left(600 \mathrm{MHz}, \mathrm{CD}_{2} \mathrm{Cl}_{2}\right.$, the proton of $\mathrm{OH}$ was omited) $\delta 9.76(\mathrm{br} \mathrm{s}, 1 \mathrm{H}), 8.39$ (dd, $J=0.6,2.2 \mathrm{~Hz}, 1 \mathrm{H}), 7.84$ (dd, $J=2.3,8.8 \mathrm{~Hz}, 1 \mathrm{H}), 6.93(\mathrm{dd}, J=0.6,8.8 \mathrm{~Hz}, 1 \mathrm{H}), 6.23$ (ddd, $J=2.3,4.5,10.5 \mathrm{~Hz}, 1$ H), $5.74(\mathrm{dt}, J=1.5,10.5 \mathrm{~Hz}, 1 \mathrm{H}), 5.26(\mathrm{~m}, 1 \mathrm{H}), 5.14(\mathrm{~m}, 1 \mathrm{H}), 5.05(\mathrm{~d}, J=2.9 \mathrm{~Hz}, 1$ H), $4.64(\mathrm{~m}, 1 \mathrm{H}), 4.55(\mathrm{~d}, J=10.2 \mathrm{~Hz}, 1 \mathrm{H}), 4.41(\mathrm{~m}, 1 \mathrm{H}), 4.27(\mathrm{~d}, J=7.6 \mathrm{~Hz}, 1 \mathrm{H})$, $4.20(\mathrm{~m}, 1 \mathrm{H}), 3.91(\mathrm{dd}, J=3.0,8.4 \mathrm{~Hz}, 1 \mathrm{H}), 3.76(\mathrm{dd}, J=1.5,8.1 \mathrm{~Hz}, 1 \mathrm{H}), 3.46$ (s, $3 \mathrm{H}), 3.44(\mathrm{~m}, 1 \mathrm{H}), 3.28(\mathrm{~m}, 1 \mathrm{H}), 3.22(\mathrm{t}, J=9.4 \mathrm{~Hz}, 1 \mathrm{H}), 3.08$ (dd, $J=1.8,8.1 \mathrm{~Hz}, 1$ H), 2.91 (dd, $J=8.9,18.5 \mathrm{~Hz}, 1 \mathrm{H}$ ), 2.59 (app. d, $J=6.3 \mathrm{~Hz}, 2 \mathrm{H}), 2.49-2.37$ (m, $10 \mathrm{H}$ ), 2.21 (m, $1 \mathrm{H}), 2.09$ (ddd, $J=2.7,7.2,15.9 \mathrm{~Hz}, 1 \mathrm{H}), 1.96-1.92(\mathrm{~m}, 2 \mathrm{H}), 1.81$ (dd, $J=4.0,14.4 \mathrm{~Hz}, 1 \mathrm{H}), 1.70(\mathrm{~m}, 1 \mathrm{H}), 1.62(\mathrm{~m}, 1 \mathrm{H}), 1.30$ (d, J=6.6 Hz, $3 \mathrm{H}), 1.21$ (d, $J=6.0 \mathrm{~Hz}, 3 \mathrm{H}), 1.14$ (t, $J=7.5 \mathrm{~Hz}, 3 \mathrm{H}), 1.08(\mathrm{~d}, J=6.2 \mathrm{~Hz}, 3 \mathrm{H}), 1.06$ (d, $J=7.0 \mathrm{~Hz}, 3$ $\mathrm{H}), 1.04(\mathrm{~s}, 3 \mathrm{H}), 0.90(\mathrm{~m}, 1 \mathrm{H}) ;{ }^{13} \mathrm{C} \mathrm{NMR}\left(150 \mathrm{MHz}, \mathrm{CD}_{2} \mathrm{Cl}_{2}\right) \delta 203.8,174.7,172.3$, 158.1, 154.3, 146.3, 128.1, 127.9, 111.3, 105.0, 97.5, 84.6, 80.9, 80.8, 77.7, 76.2, 73.7, $73.5,72.0,70.2,69.7,69.3,68.9,67.9,63.9,61.8,53.6,46.1,42.2,40.9,38.7,38.2$, $33.1,32.9,30.2,28.0,25.7,20.5,19.4,18.1,18.1,16.9,9.7$; HRMS [FAB, $\mathrm{MH}^{+}$] calcd for $\mathrm{C}_{43} \mathrm{H}_{67} \mathrm{IN}_{3} \mathrm{O}_{15} 992.3617$, found 992.3620 .

\section{Representative procedure for the NDA reaction of 2-nitrosopyridines and 5- methyl-3-nitrosoisoxazole with ergosterol (5):}

Preparation of cycloadduct 14 


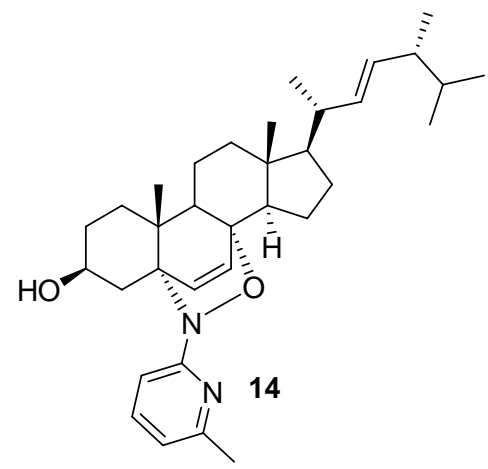

To a solution of 7 (50 mg, $0.126 \mathrm{mmol})$ in $1.5 \mathrm{~mL}$ of THF was added 6-methyl-2nitrosopyridine 3a (15.4 mg, $0.126 \mathrm{mmol}, 1.0 \mathrm{eq})$ in $1 \mathrm{~mL}$ of $\mathrm{CH}_{2} \mathrm{Cl}_{2}$ at $0{ }^{\circ} \mathrm{C}$. The resulting reaction mixture was stirred at $0{ }^{\circ} \mathrm{C}$ for $10 \mathrm{~min}$. The solvent was removed under reduced pressure. ${ }^{1} \mathrm{H}$ NMR of the crude reaction mixture showed $100 \%$ conversion with $>90 \%$ purity of cycloaddcut 14 . Quick flash chromatography of the crude product on silica gel with hexanes/EtOAc (15:1) afforded 14 (60 mg, 0.116 mmol, 92\%) as white crystals. A single crystal was grown by slow evaporation of solven from a solution of 14 in hexanes $/ \mathrm{CH}_{2} \mathrm{Cl}_{2}$. mp $118-120{ }^{\circ} \mathrm{C} ;[\alpha]_{\mathrm{D}}{ }^{20}=-10.5(c=$ $\left.0.8, \mathrm{CHCl}_{3}\right)$; IR 3498, 2952, 2869, 1574, 1445, 1371, 1274, 1157, 1020, 967, 925, $784,531 \mathrm{~cm}^{-1} ;{ }^{1} \mathrm{H}$ NMR $\left(500 \mathrm{MHz}, \mathrm{CDCl}_{3}\right) \delta 7.35(\mathrm{t}, J=7.78 \mathrm{~Hz}, 1 \mathrm{H}), 6.74(\mathrm{~d}$, $J=7.38 \mathrm{~Hz}, 1 \mathrm{H}), 6.68(\mathrm{~d}, J=8.18 \mathrm{~Hz}, 1 \mathrm{H}), 6.36(\mathrm{~d}, J=8.38 \mathrm{~Hz}, 1 \mathrm{H}), 5.71(\mathrm{~d}, J=8.38$ $\mathrm{Hz}, 1 \mathrm{H}), 5.25(\mathrm{dd}, J=7.46,15.3 \mathrm{~Hz}, 1 \mathrm{H}), 5.18(\mathrm{dd}, J=8.15,15.3 \mathrm{~Hz}, 1 \mathrm{H}), 5.12(\mathrm{~m}, 1$ H), 2.58 (ddd, $J=1.38,4.64,13.6 \mathrm{~Hz}, 1 \mathrm{H}), 2.43(\mathrm{~s}, 3 \mathrm{H}), 2.23(\mathrm{~m}, 1 \mathrm{H}), 1.37-2.08$ (m, $16 \mathrm{H}), 1.17-1.31(\mathrm{~m}, 3 \mathrm{H}), 1.02(\mathrm{~d}, J=6.60 \mathrm{~Hz}, 3 \mathrm{H}), 0.94(\mathrm{~s}, 3 \mathrm{H}), 0.93(\mathrm{~d}, J=6.84 \mathrm{~Hz}$, $3 \mathrm{H}), 0.87(\mathrm{~s}, 3 \mathrm{H}), 0.85(\mathrm{~d}, J=6.84 \mathrm{~Hz}, 3 \mathrm{H}), 0.83(\mathrm{~d}, J=6.84 \mathrm{~Hz}, 3 \mathrm{H})$; ${ }^{13} \mathrm{C} \mathrm{NMR}$ $\left(125 \mathrm{MHz}, \mathrm{CDCl}_{3}\right) \delta 163.8,155.3,137.1,135.6,134.1,132.3,127.5,118.1,113.7$, $77.7,68.9,67.3,56.6,53.5,44.3,43.0,40.0,39.7,39.0,37.0,34.3,33.3,30.3,28.8$, 24.7, 24.1, 21.3, 21.1, 20.5, 19.8, 18.8, 17.8, 13.2; HRMS [FAB, $\left.\mathrm{MH}^{+}\right]$calcd for $\mathrm{C}_{34} \mathrm{H}_{51} \mathrm{~N}_{2} \mathrm{O}_{2}$ 519.3951, found 519.3955.

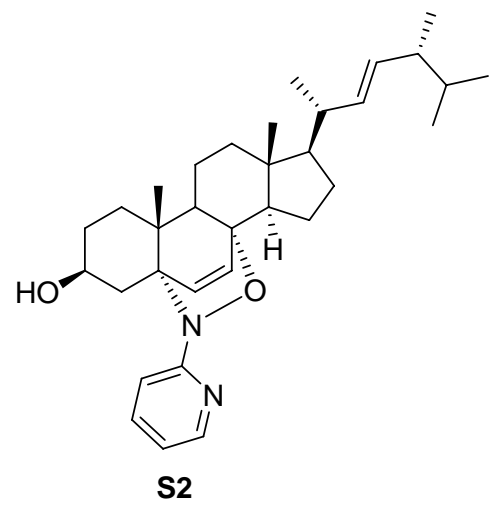

\section{Egosterol cycloadduct S2}

Compound S2 was obtained as white crystals in $95 \%$ yield. mp $89-91{ }^{\circ} \mathrm{C} ;[\alpha]_{\mathrm{D}}{ }^{20}$ $=7.1\left(c=1.9, \mathrm{CHCl}_{3}\right) ;$ IR 3480, 2953, 2930, 2869, 1574, 1444, 1372, 1274, 1157, 
1020, 969, 924, 784, $685 \mathrm{~cm}^{-1} ;{ }^{1} \mathrm{H}$ NMR $\left(500 \mathrm{MHz}, \mathrm{CDCl}_{3}\right) \delta 8.27(\mathrm{~m}, 1 \mathrm{H}), 7.45(\mathrm{~m}$, $1 \mathrm{H}), 6.85-6.88(\mathrm{~m}, 2 \mathrm{H}), 6.37$ (d, $J=8.37 \mathrm{~Hz}, 1 \mathrm{H}), 5.71(\mathrm{~d}, J=8.37 \mathrm{~Hz}, 1 \mathrm{H}), 5.25$ (dd, $J=7.46,15.3 \mathrm{~Hz}, 1 \mathrm{H}), 5.17$ (dd, $J=8.30,15.3 \mathrm{~Hz}, 1 \mathrm{H}), 5.03(\mathrm{~m}, 1 \mathrm{H}), 2.59$ (ddd, $J=1.20,4.59,13.6 \mathrm{~Hz}, 1 \mathrm{H}), 2.21(\mathrm{~m}, 1 \mathrm{H}), 1.38-2.08(\mathrm{~m}, 16 \mathrm{H}), 1.19-1.32$ (m, $3 \mathrm{H})$, 1.02 (d, J=6.60 Hz, $3 \mathrm{H}), 0.94$ (s, $3 \mathrm{H}), 0.93$ (d, $J=6.84 \mathrm{~Hz}, 3 \mathrm{H}), 0.87$ (s, $3 \mathrm{H}), 0.85$ $(\mathrm{d}, J=6.84 \mathrm{~Hz}, 3 \mathrm{H}), 0.83(\mathrm{~d}, J=6.84 \mathrm{~Hz}, 3 \mathrm{H}) ;{ }^{13} \mathrm{C} \mathrm{NMR}\left(125 \mathrm{MHz}, \mathrm{CDCl}_{3}\right) \delta 164.5$, $146.8,136.7,135.5,134.1,132.3,127.4,118.7,117.1,77.8,68.9,67.0,56.5,53.5$, $53.4,44.3,42.9,40.0,39.6,38.9,36.8,34.3,33.2,30.3,28.7,24.0,21.2,21.0,20.1$, 19.8, 18.8, 17.7, 13.2; HRMS [FAB, $\mathrm{MH}^{+}$] calcd for $\mathrm{C}_{33} \mathrm{H}_{49} \mathrm{~N}_{2} \mathrm{O}_{2} 505.3794$, found 505.3804 .

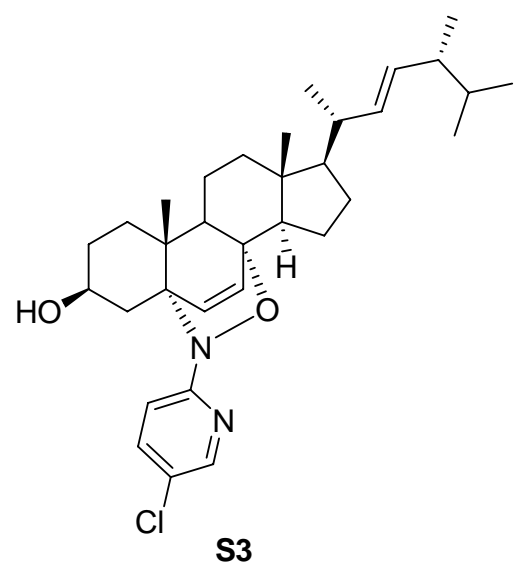

\section{Egosterol cycloadduct S3}

Compound S3 was obtained as white crystals in $90 \%$ yield. mp $114-116{ }^{\circ} \mathrm{C}$; $[\alpha]_{\mathrm{D}}^{20}=+22.3\left(c=0.2, \mathrm{CHCl}_{3}\right)$; IR $(\mathrm{KBr}) 3423,2957,2871,1575,1454,1374,1263$, 1113, 1040, 968, 923, 794, 644 $\mathrm{cm}^{-1}$; ${ }^{1} \mathrm{H}$ NMR $\left(500 \mathrm{MHz}, \mathrm{CDCl}_{3}\right) \delta 8.22(\mathrm{~d}, J=2.7$ $\mathrm{Hz}, 1 \mathrm{H}), 7.40$ (dd, $J=2.7,8.9 \mathrm{~Hz}, 1 \mathrm{H}), 6.82(\mathrm{~d}, J=8.9 \mathrm{~Hz}, 1 \mathrm{H}), 6.36$ (d, $J=8.4 \mathrm{~Hz}, 1$ H), $5.71(\mathrm{~d}, J=8.4 \mathrm{~Hz}, 1 \mathrm{H}), 5.25$ (dd, $J=7.5,15.3 \mathrm{~Hz}, 1 \mathrm{H}), 5.17$ (dd, $J=8.4,15.3 \mathrm{~Hz}$, $1 \mathrm{H}), 4.94(\mathrm{~m}, 1 \mathrm{H}), 2.59$ (dd, $J=3.7,13.7 \mathrm{~Hz}, 1 \mathrm{H}), 2.16$ (m, $1 \mathrm{H}), 2.08-1.19$ (m, 19 H), 1.02 (d, J=6.6 Hz, $3 \mathrm{H}), 0.94$ (s, $3 \mathrm{H}), 0.93$ (d, J=6.9 Hz, $3 \mathrm{H}), 0.86$ (s, $3 \mathrm{H}), 0.85$ (overlap d, $J=6.84 \mathrm{~Hz}, 3 \mathrm{H}$ ), 0.83 (overlap d, $J=6.84 \mathrm{~Hz}, 3 \mathrm{H}$ ); ${ }^{13} \mathrm{C}$ NMR $(125 \mathrm{MHz}$, $\left.\mathrm{CDCl}_{3}\right) \delta 162.9,145.4,136.5,135.5,134.1,132.4,127.5,126.2,117.8,78.1,69.3$, 67.1, 56.5, 53.5, 53.4, 44.4, 43.0, 40.0, 39.7, 39.0, 36.8, 34.4, 33.3, 30.4, 28.8, 24.1, $21.3,21.1,20.2,19.9,18.8,17.8,13.2$; HRMS $\left[\mathrm{FAB}, \mathrm{MH}^{+}\right]$calcd for $\mathrm{C}_{33} \mathrm{H}_{48} \mathrm{~N}_{2} \mathrm{O}_{2}$ 539.3404, found 539.3416. 


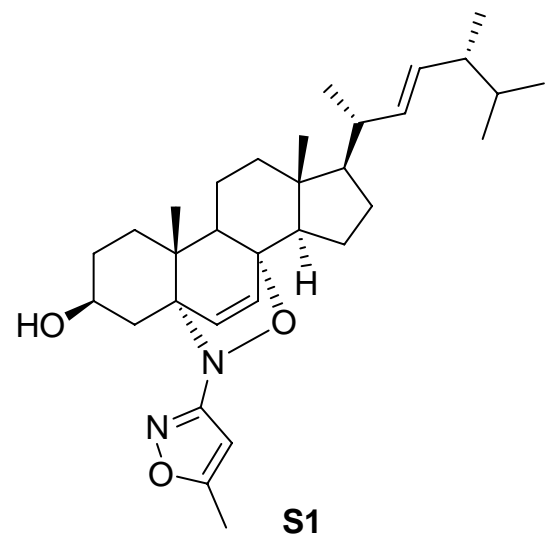

\section{Egosterol cycloadduct S1}

Compound S1 was obtained as white crystals in $92 \%$ yield. mp $155-156{ }^{\circ} \mathrm{C}$; $[\alpha]_{\mathrm{D}}{ }^{20}=-47.5\left(c=0.1, \mathrm{CHCl}_{3}\right)$; IR 3498, 2952, 2869, 1574, 1445, 1371, 1274, 1157, 1020, 967, 925, 784, 531 $\mathrm{cm}^{-1} ;{ }^{1} \mathrm{H}$ NMR $\left(500 \mathrm{MHz}, \mathrm{CDCl}_{3}\right) \delta 6.32(\mathrm{~d}, J=8.47 \mathrm{~Hz}, 1$ H), $5.92(\mathrm{~d}, J=8.47 \mathrm{~Hz}, 1 \mathrm{H}), 5.62(\mathrm{t}, J=0.78 \mathrm{~Hz}, 1 \mathrm{H}), 5.25(\mathrm{dd}, J=7.40,15.3 \mathrm{~Hz}, 1$ H), $5.16(\mathrm{dd}, J=8.30,15.3 \mathrm{~Hz}, 1 \mathrm{H}), 4.48(\mathrm{~m}, 1 \mathrm{H}), 2.57$ (ddd, $J=1.40,4.79,13.9 \mathrm{~Hz}$, $1 \mathrm{H}), 2.28(\mathrm{t}, J=0.78 \mathrm{~Hz}, 3 \mathrm{H}), 1.16-2.20(\mathrm{~m}, 20 \mathrm{H}), 1.02$ (d, J=6.58 Hz, $3 \mathrm{H}), 0.925$ $(\mathrm{s}, 3 \mathrm{H}), 0.924(\mathrm{~d}, J=6.67 \mathrm{~Hz}, 3 \mathrm{H}), 0.84$ (d, overlap $J=6.72 \mathrm{~Hz}, 3 \mathrm{H}$ ), 0.839 (s, overlap, $3 \mathrm{H}), 0.83(\mathrm{~d}$, overlap, $J=7.52 \mathrm{~Hz}, 3 \mathrm{H}) ;{ }^{13} \mathrm{C} \mathrm{NMR}\left(125 \mathrm{MHz}, \mathrm{CDCl}_{3}\right) \delta$ 170.9, 167.9, 135.4, 135.1, 132.4, 128.1, 98.9, 78.0, 67.6, 66.3, 65.8, 56.5, 53.2, 53.2, 44.3, 42.9, 40.0, 39.6, 38.5, 36.0, 34.5, 33.2, 29.9, 28.7, 24.0, 21.0, 20.1, 19.8, 18.5, 17.7, 13.2, 12.6; HRMS [FAB, $\mathrm{MH}^{+}$] calcd for $\mathrm{C}_{32} \mathrm{H}_{49} \mathrm{~N}_{2} \mathrm{O}_{3}$ 509.3743, found 509.3754 .

NDA reaction of 6-methyl-2-nitrosopyridine (3a) with reductiomycin (6).

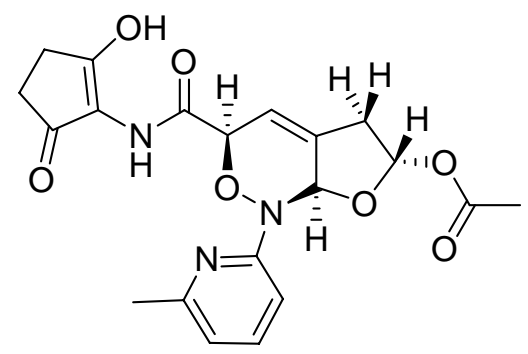

15

To a solution of 6 (15 mg, $0.049 \mathrm{mmol})$ in $1.5 \mathrm{~mL}$ of THF was added 6-methyl-2nitrosopyridine 3a $(6.0 \mathrm{mg}, 0.049 \mathrm{mmol}, 1.0 \mathrm{eq})$ in $0.5 \mathrm{~mL}$ of $\mathrm{CH}_{2} \mathrm{Cl}_{2}$ at $0{ }^{\circ} \mathrm{C}$. The resulting reaction mixture was stirred at $0{ }^{\circ} \mathrm{C}$ for $15 \mathrm{~min}$. The solvent was removed under reduced pressure. Cycloadduct 15 was obtained as a single isomer in excellent purity based on ${ }^{1} \mathrm{H}$ NMR analysis $(>90 \%)$. While compound 15 was found to decompose in solvents (over 6-8h in THF and 3-4h in $\mathrm{CD}_{2} \mathrm{Cl}_{2}$ ) as well as upon silica chromatography, it is stable over weeks when stored as a solid form at $-20{ }^{\circ} \mathrm{C}$. The crude cyloadduct $(>90 \%)$ was used for NMR studies. mp $110-112{ }^{\circ} \mathrm{C} ;[\alpha]_{\mathrm{D}}{ }^{20}=-141.4$ $\left(c=0.1, \mathrm{CHCl}_{3}\right)$; IR 3213, 2925, 2856, 1726, 1618, 1542, 1452, 1358, 1225, 972, 784, 
$544 \mathrm{~cm}^{-1}$ HRMS [FAB, $\mathrm{MH}^{+}$] calcd for $\mathrm{C}_{20} \mathrm{H}_{22} \mathrm{~N}_{3} \mathrm{O}_{7} 416.1458$, found $416.1460 .{ }^{1} \mathrm{H}$ NMR and ${ }^{13} \mathrm{C}$ NMR chemical shift assignments are listed in Table S2.

\section{Isoforocidin cycloadduct 16}

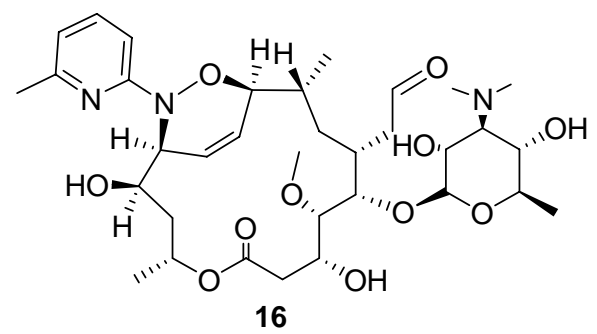

To a solution of 7 (30 mg, $0.054 \mathrm{mmol}$ ) in $1.5 \mathrm{~mL}$ of THF was added 6-methyl-2nitrosopyridine 3a $(6.6 \mathrm{mg}, 0.054 \mathrm{mmol}, 1.0 \mathrm{eq})$ in $0.5 \mathrm{~mL}$ of $\mathrm{CH}_{2} \mathrm{Cl}_{2}$ at $0{ }^{\circ} \mathrm{C}$. The resulting reaction mixture was warmed to room temperature and then stirred for 20 min. The solvent was removed under reduced pressure. Flash chromatography of the crude product on silica gel with $\mathrm{CH}_{2} \mathrm{Cl}_{2} / \mathrm{MeOH} / 0.5 \% \mathrm{Et}_{3} \mathrm{~N}$ (20:1 to 12:1) afforded 16 (33 mg, $0.048 \mathrm{mmol}, 90 \%$ ) as a light yellow solid. $\mathrm{mp} 151-153{ }^{\circ} \mathrm{C} ;[\alpha]_{\mathrm{D}}{ }^{20}=-46.9(\mathrm{C}$ $\left.=0.5, \mathrm{CHCl}_{3}\right)$; IR 3265, 2920, 1719, 1589, 1450, 1377, 1287, 1170, 1064, 1034, 835, $787,733 \mathrm{~cm}^{-1}$; HRMS [FAB, $\mathrm{MH}^{+}$] calcd for $\mathrm{C}_{34} \mathrm{H}_{54} \mathrm{~N}_{3} \mathrm{O}_{11} 680.3758$, found 680.3776 . ${ }^{1} \mathrm{H}$ NMR and ${ }^{13} \mathrm{C}$ NMR chemical shift assignments are listed in Table S3.

\section{Colchicine cycloadduct 17}

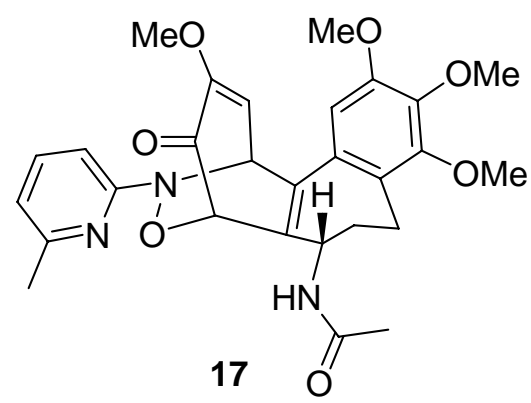

To a solution of $8(50 \mathrm{mg}, 0.125 \mathrm{mmol})$ in $1.5 \mathrm{~mL}$ of MeOH was added 6-methyl2-nitrosopyridine 3a $(31 \mathrm{mg}, 0.25 \mathrm{mmol})$ at RT. The resulting reaction mixture was stirred at RT for $15 \mathrm{~h}$. The solvent was removed under reduced pressure. Flash chromatography of the crude product on silica gel with $\mathrm{CH}_{2} \mathrm{Cl}_{2}$ /acetone (1:1) afforded 17 (55 mg, $0.106 \mathrm{mmol}, 85 \%)$ as a white solid. A single crystal was grown by slow evaporation solvent from 17 in $\mathrm{MeOH}$. mp 124-126 ${ }^{\circ} \mathrm{C} ;[\alpha]_{\mathrm{D}}{ }^{20}=-140.4(c=0.2$, $\mathrm{CHCl}_{3}$ ); IR 3265, 2937, 1702, 1589, 1572, 1450, 1325, 1251, 1117, 1091, 987, 787 $\mathrm{cm}^{-1} ;{ }^{1} \mathrm{H}$ NMR $\left(500 \mathrm{MHz}, \mathrm{CD}_{3} \mathrm{OD}\right) \delta 7.54(\operatorname{app~t}, J=7.6 \mathrm{~Hz}, 1 \mathrm{H}), 7.01(\mathrm{~d}, J=8.2 \mathrm{~Hz}$, $1 \mathrm{H}), 6.71(\mathrm{~d}, J=7.4 \mathrm{~Hz}, 1 \mathrm{H}), 6.52(\mathrm{~s}, 1 \mathrm{H}), 6.45$ (d, $J=9.4 \mathrm{~Hz}, 1 \mathrm{H}), 6.26(\mathrm{~d}, J=9.4 \mathrm{~Hz}$, $1 \mathrm{H}), 5.40(\mathrm{~d}, J=0.4 \mathrm{~Hz}, 1 \mathrm{H}), 4.25(\mathrm{dd}, J=7.2,12.9 \mathrm{~Hz}, 1 \mathrm{H}), 3.86(\mathrm{~s}, 3 \mathrm{H}), 3.83$ (s, 3 H), $3.82(\mathrm{~s}, 3 \mathrm{H}), 3.70(\mathrm{~s}, 3 \mathrm{H}), 2.17(\mathrm{~m}, 1 \mathrm{H}), 2.02$ (s, $3 \mathrm{H}), 1.95$ (s, $3 \mathrm{H}), 1.99-1.78$ $(\mathrm{m}, 2 \mathrm{H}), 0.83(\mathrm{~m}, 1 \mathrm{H}) ;{ }^{13} \mathrm{C} \mathrm{NMR}\left(75 \mathrm{MHz}, \mathrm{CD}_{3} \mathrm{OD} / \mathrm{CDCl}_{3}\right) \delta 191.1,172.9,163.9$, 157.9 , 154.9, 153.1, 153.0, 142.8, 142.1, 139.9, 137.0, 129.9, 125.1, 118.2, 114.7, 
$110.1,109.7,82.3,62.1,61.6,61.1,56.7,55.8,48.7,41.4,30.5,24.0,22.8$; HRMS [FAB, $\mathrm{MH}^{+}$] calcd for $\mathrm{C}_{28} \mathrm{H}_{32} \mathrm{~N}_{3} \mathrm{O}_{7} 522.2240$, found 522.2261.

\section{Thebaine cycloadduct 18}

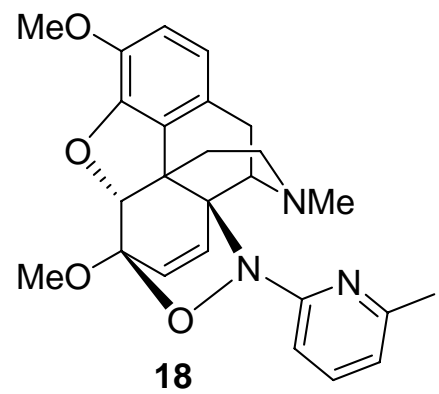

To a solution of 9 (50 $\mathrm{mg}, 0.161 \mathrm{mmol})$ in $1.5 \mathrm{~mL}$ of THF was added 6-methyl-2nitrosopyridine 3a $(19.7 \mathrm{mg}, 0.161 \mathrm{mmol}, 1.0 \mathrm{eq})$ in $1 \mathrm{~mL}$ of $\mathrm{CH}_{2} \mathrm{Cl}_{2}$ at $0{ }^{\circ} \mathrm{C}$. The resulting reaction mixture was stirred at $0{ }^{\circ} \mathrm{C}$ for $10 \mathrm{~min}$. The solvent was removed under reduced pressure. ${ }^{1} \mathrm{H}$ NMR of the crude reaction mixture showed $100 \%$ conversion with $>95 \%$ purity of cycloaddcut 18 as a light yellow solid. A single crystal was grown by slow diffusion of hexanes to $\mathrm{CH}_{2} \mathrm{Cl}_{2}$. mp $147-148{ }^{\circ} \mathrm{C} ;[\alpha]_{\mathrm{D}}{ }^{20}=$ $-63\left(c=0.3, \mathrm{CHCl}_{3}\right)$; IR (KBr) 3450, 3145, 2970, 2942, 1587, 1575, 1445, 1401, 1288, 1223, 1169, 892, 787, 726, $696 \mathrm{~cm}^{-1}$; ${ }^{1} \mathrm{H} \mathrm{NMR}\left(500 \mathrm{MHz}, \mathrm{CDCl}_{3}\right) \delta 7.38$ (app t, $J=7.9 \mathrm{~Hz}, 1 \mathrm{H}), 6.76(\mathrm{~d}, J=8.2 \mathrm{~Hz}, 1 \mathrm{H}), 6.67(\mathrm{~d}, J=8.2 \mathrm{~Hz}, 1 \mathrm{H}), 6.64(\mathrm{~d}, J=7.7 \mathrm{~Hz}$, $1 \mathrm{H}), 6.58(\mathrm{~d}, J=8.2 \mathrm{~Hz}, 1 \mathrm{H}), 6.00(\mathrm{dd}, J=1.1,8.9 \mathrm{~Hz}, 1 \mathrm{H}), 5.73(\mathrm{~d}, J=8.9 \mathrm{~Hz}, 1$ H), $4.68(\mathrm{~d}, J=1.1 \mathrm{~Hz}, 1 \mathrm{H}), 3.81(\mathrm{~s}, 3 \mathrm{H}), 3.64(\mathrm{~s}, 3 \mathrm{H}), 3.45(\mathrm{~d}, J=18.5 \mathrm{~Hz}, 1 \mathrm{H})$, 2.79-2.52 (m, $5 \mathrm{H}), 2.56(\mathrm{~s}, 3 \mathrm{H}), 2.40(\mathrm{~s}, 3 \mathrm{H}), 1.95(\mathrm{~m}, 1 \mathrm{H}) ;{ }^{13} \mathrm{C} \mathrm{NMR}(125 \mathrm{MHz}$, $\left.\mathrm{CDCl}_{3}\right) \delta 164.2,156.1,148.1,142.3,138.8,137.8,128.0,122.2,119.7,116.6,114.3$, $110.3,103.5,90.5,67.2,60.2,56.8,53.1,48.4,45.5,43.3,33.5,24.6,23.7$; HRMS [FAB, $\mathrm{MH}^{+}$] calcd for $\mathrm{C}_{25} \mathrm{H}_{27} \mathrm{~N}_{3} \mathrm{O}_{4} 434.2080$, found 434.2072.

\section{References:}

(10) Taylor, E. C.; Tseng, C. P.; Rampal, J. B. J. Org. Chem. 1982, 47, 552-555. 

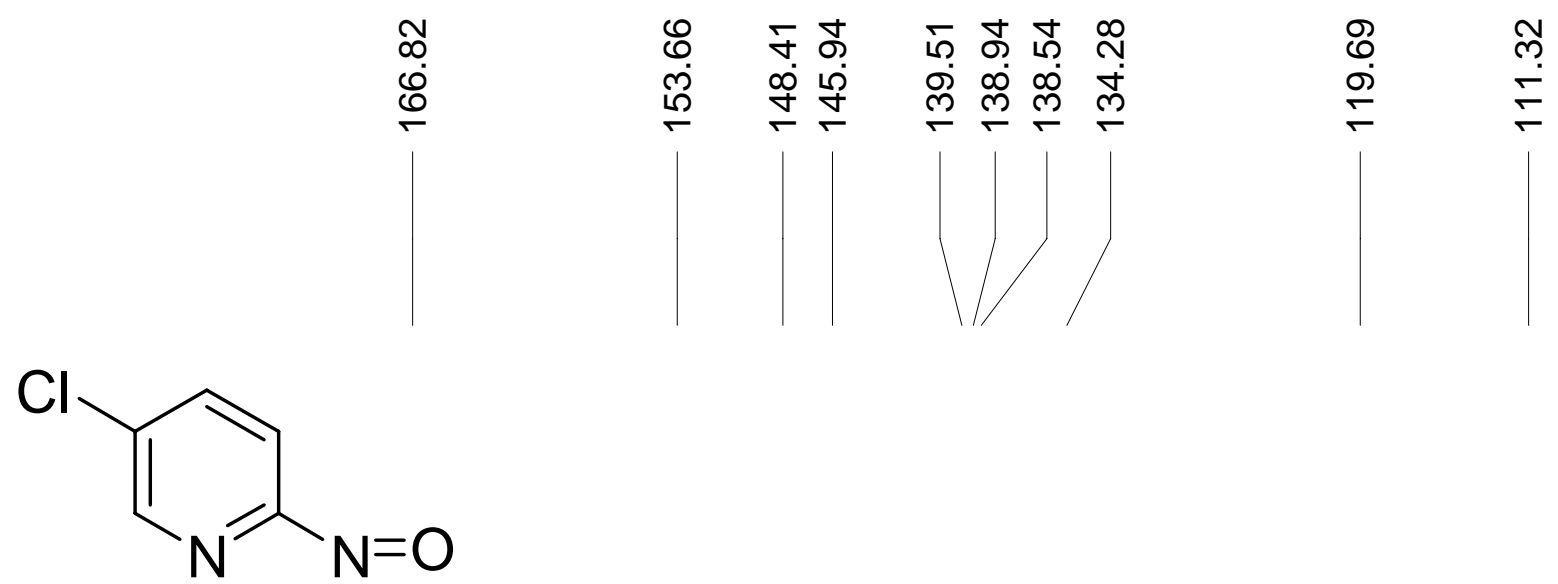

11

$\left({ }^{13} \mathrm{C} \mathrm{NMR}, 125 \mathrm{MHz}, \mathrm{CDCl}_{3}\right)$ 


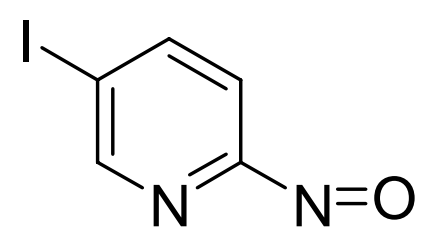

12

$\left({ }^{1} \mathrm{H} \mathrm{NMR}, 500 \mathrm{MHz}, \mathrm{CDCl}_{3}\right)$

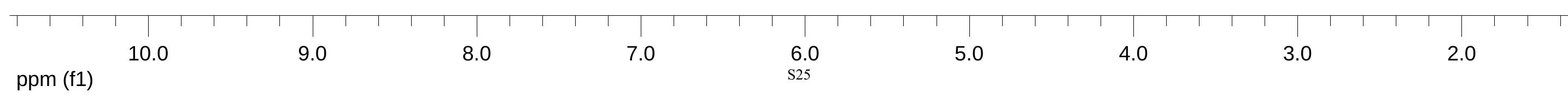



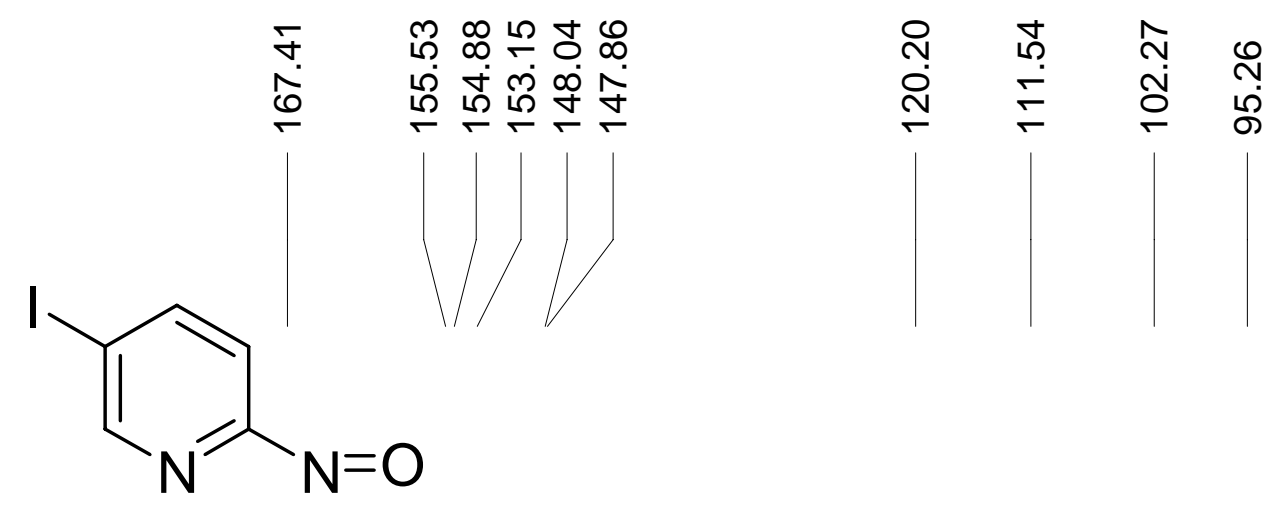

\section{2}

$\left({ }^{13} \mathrm{C} \mathrm{NMR}, 125 \mathrm{MHz}, \mathrm{CDCl}_{3}\right)$ 


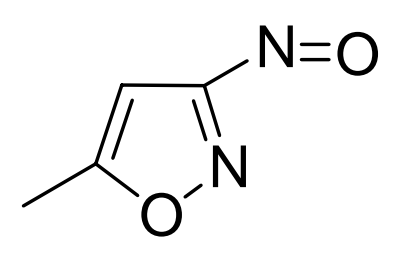

13

$\left({ }^{1} \mathrm{H}\right.$ NMR, $\left.500 \mathrm{MHz}, \mathrm{CDCl}_{3}\right)$

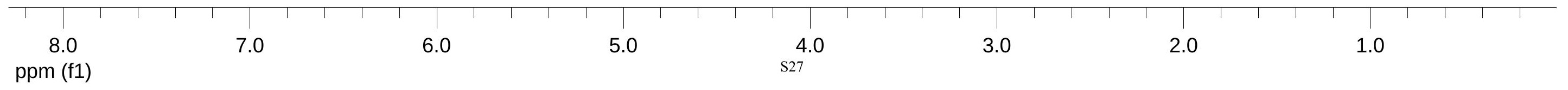




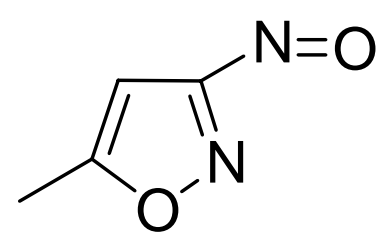

13

$\left({ }^{13} \mathrm{C} \mathrm{NMR,} 125 \mathrm{MHz}, \mathrm{CDCl}_{3}\right)$ 


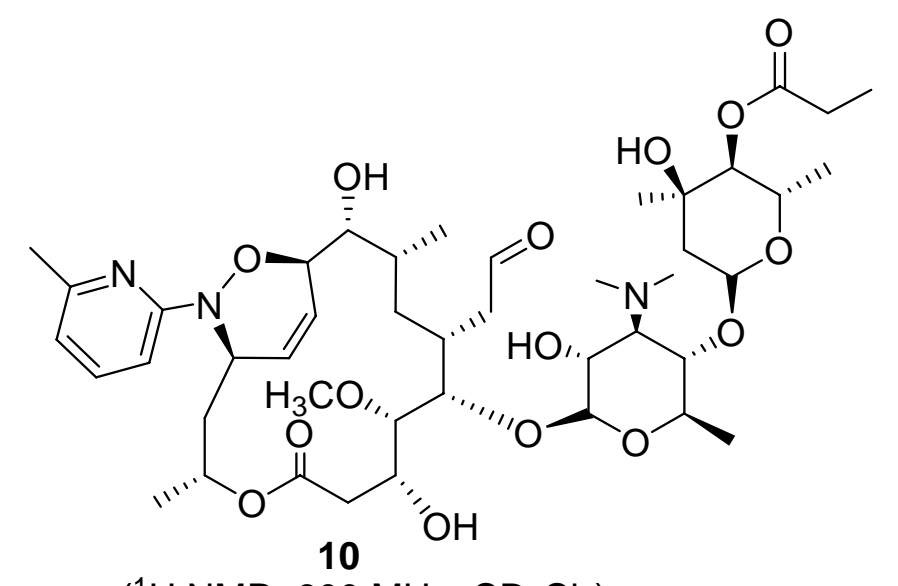

$\left({ }^{1} \mathrm{H} N M R, 600 \mathrm{MHz}, \mathrm{CD}_{2} \mathrm{Cl}_{2}\right)$

$$
\begin{aligned}
& T \\
& \mathrm{pp}
\end{aligned}
$$$$
10.0
$$$$
\text { ppm (t1) }
$$ 


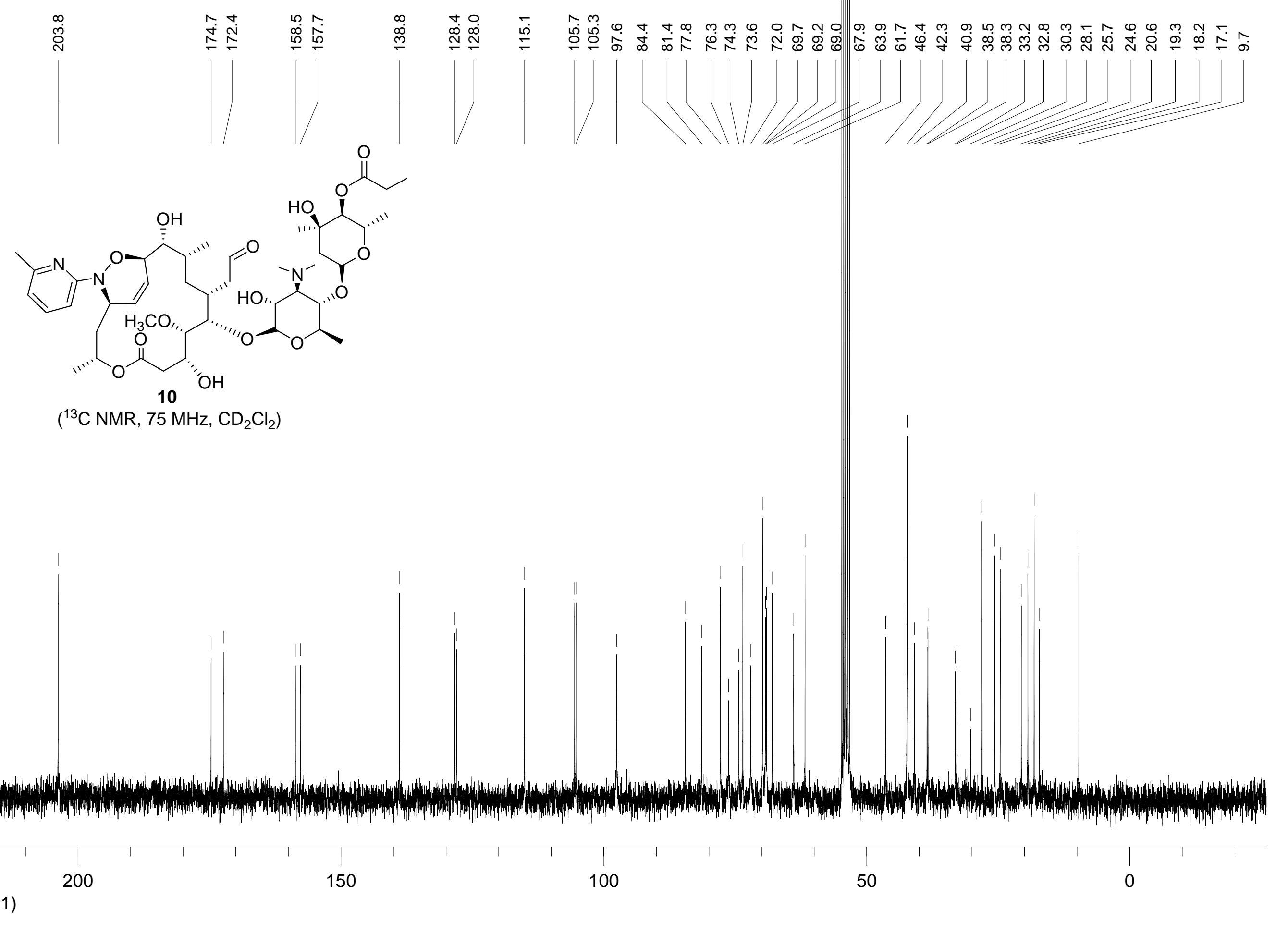




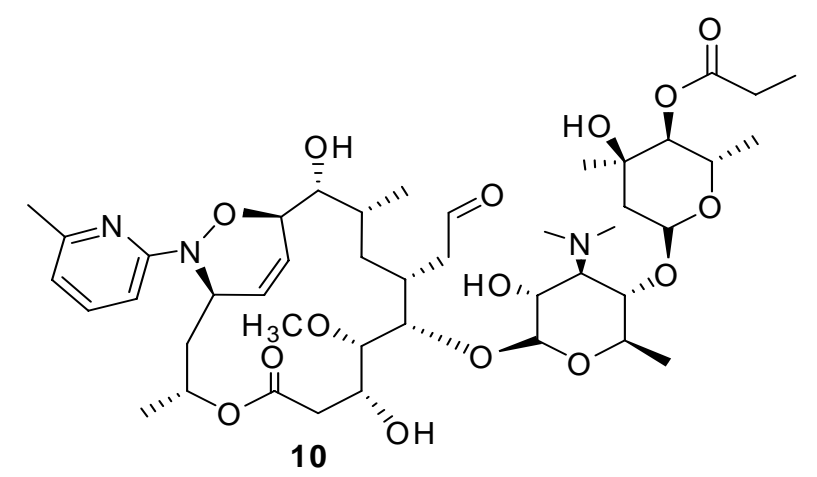

$\left({ }^{1} \mathrm{H}\right.$ NMR, $\left.500 \mathrm{MHz}, \mathrm{CD}_{2} \mathrm{Cl}_{2}\right)$

${ }^{1} \mathrm{H}$ NMR of the 'crude' 10

(Directly from the reaction mixture of $1: 1 \mathbf{4}$ and $\mathbf{3 a}$ in $C \mathrm{D}_{2} \mathrm{Cl}_{2}$ )
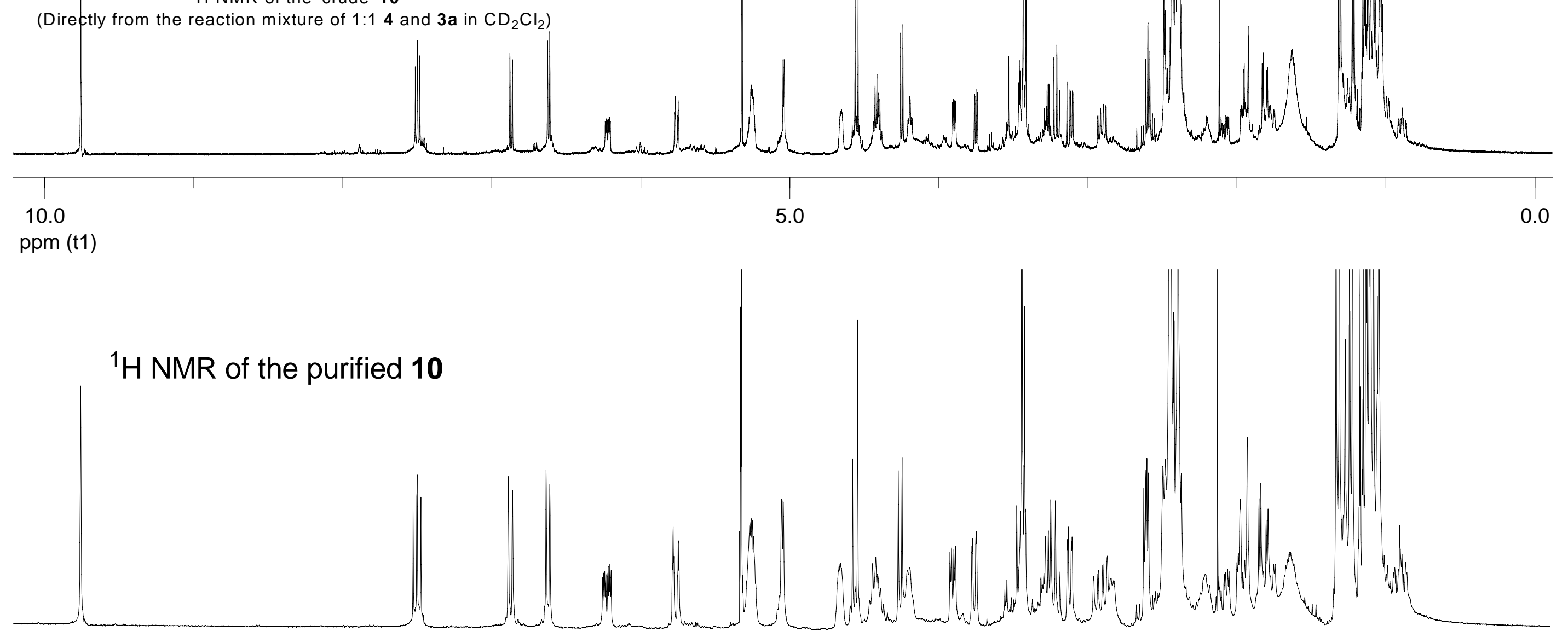


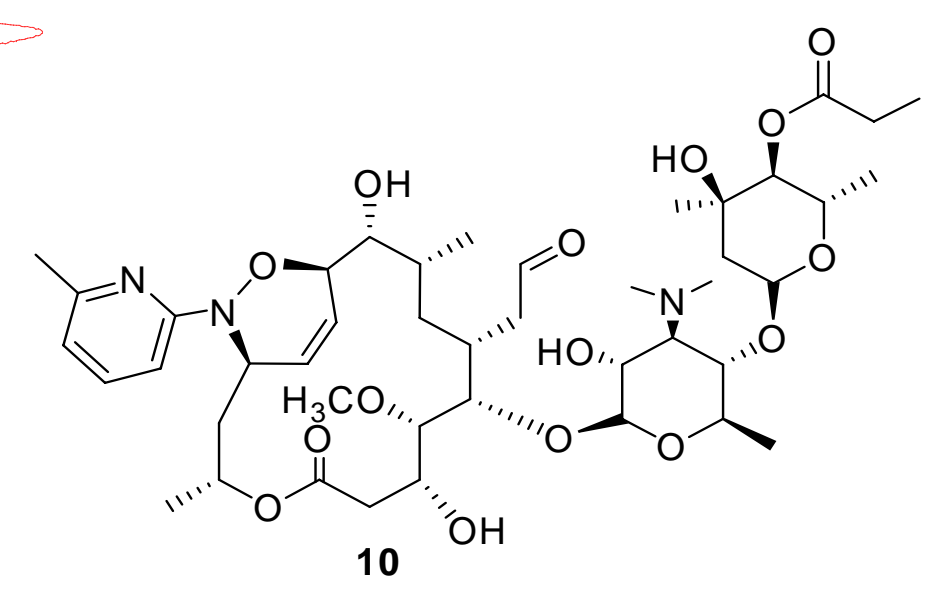

(2D-ROSEY, $600 \mathrm{MHz}, \mathrm{CDCl}_{3}$ )

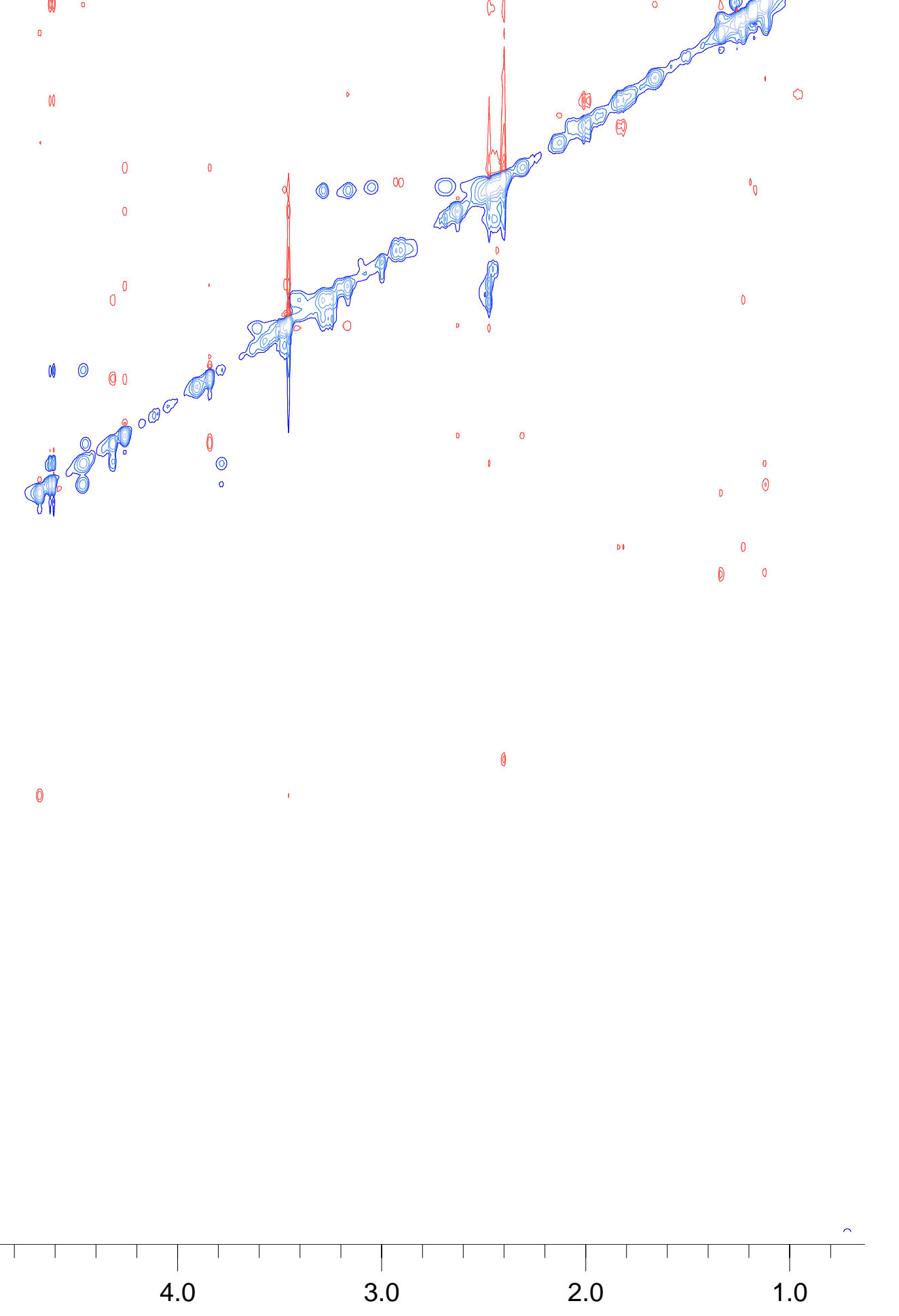




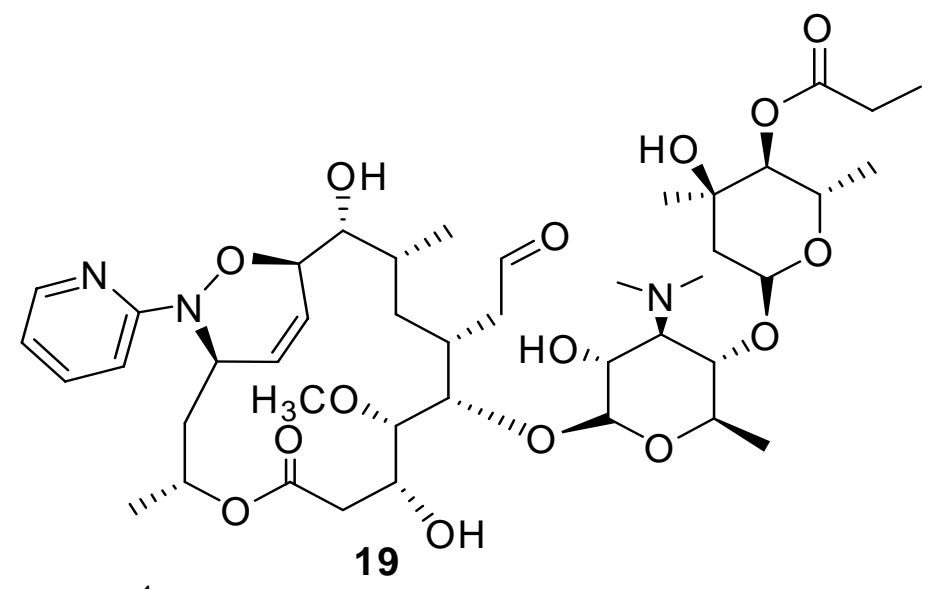

$\left({ }^{1} \mathrm{H}\right.$ NMR, $\left.600 \mathrm{MHz}, \mathrm{CD}_{2} \mathrm{Cl}_{2}\right)$ 


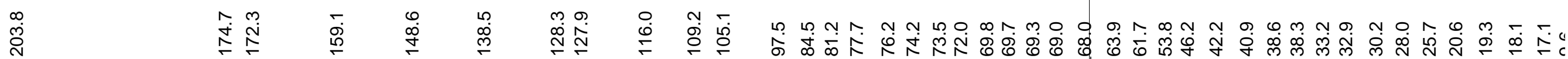

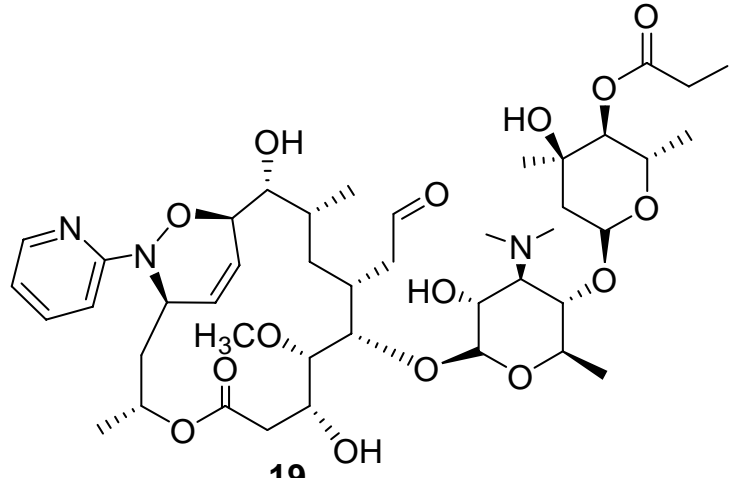

19 " $\mathrm{OH}$

$\left({ }^{13} \mathrm{C}\right.$ NMR, $\left.150 \mathrm{MHz}, \mathrm{CD}_{2} \mathrm{Cl}_{2}\right)$ 


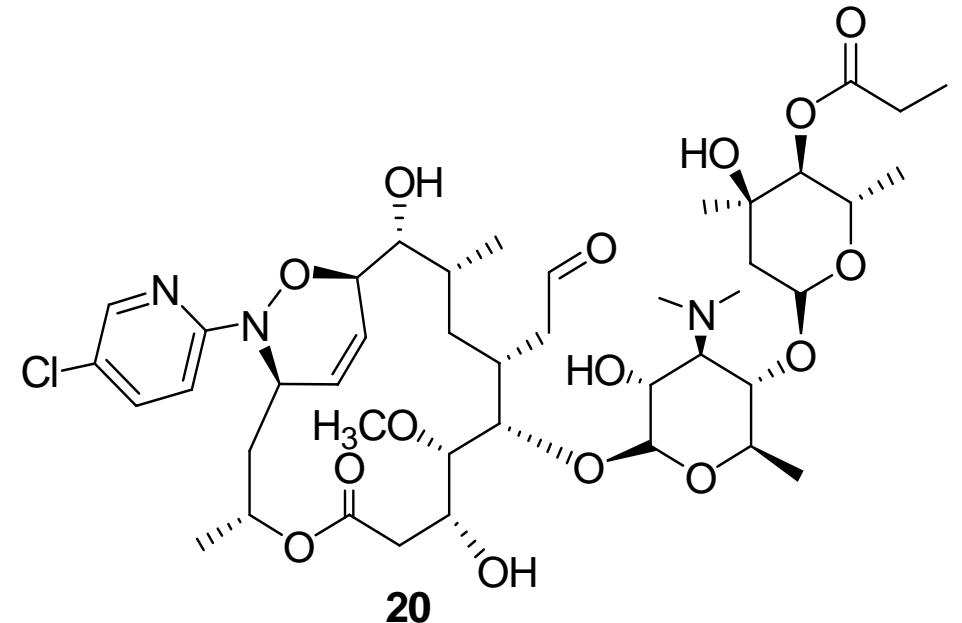

$\left({ }^{1} \mathrm{H}\right.$ NMR, $\left.600 \mathrm{MHz}, \mathrm{CD}_{2} \mathrm{Cl}_{2}\right)$ 


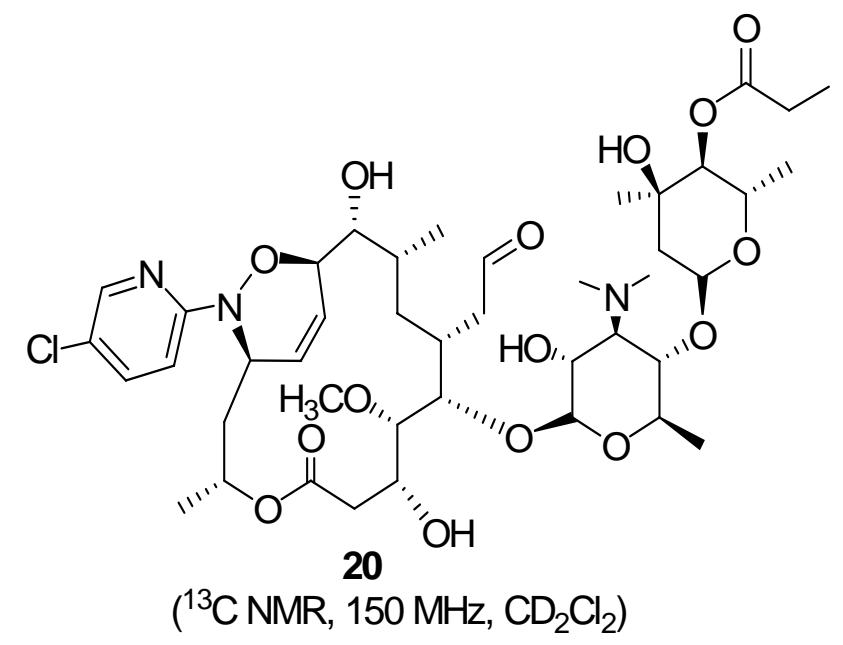



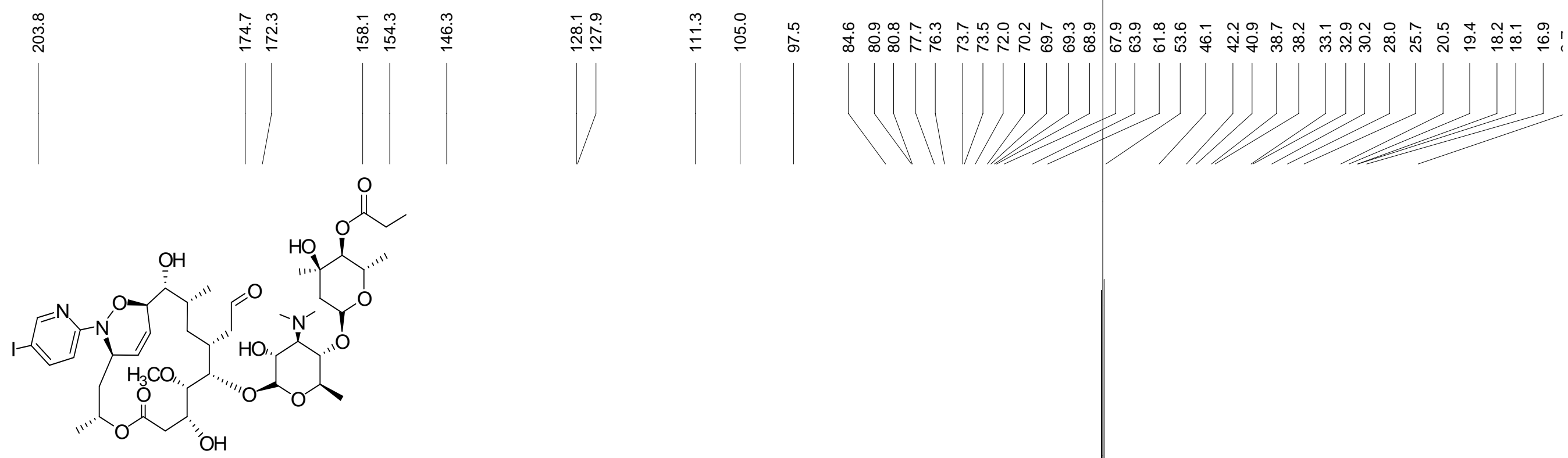

21

$\left({ }^{13} \mathrm{CNMR}, 150 \mathrm{MHz}, \mathrm{CD}_{2} \mathrm{Cl}_{2}\right)$ 


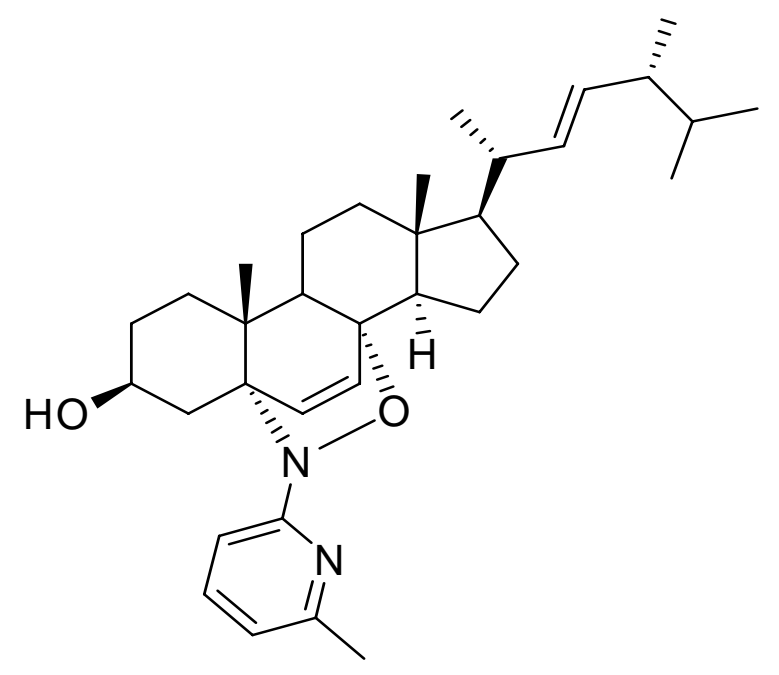

14

${ }^{1} \mathrm{H}$ NMR $\left(500 \mathrm{MHz}, \mathrm{CDCl}_{3}\right)$

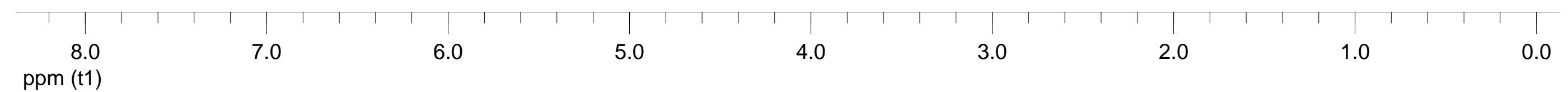



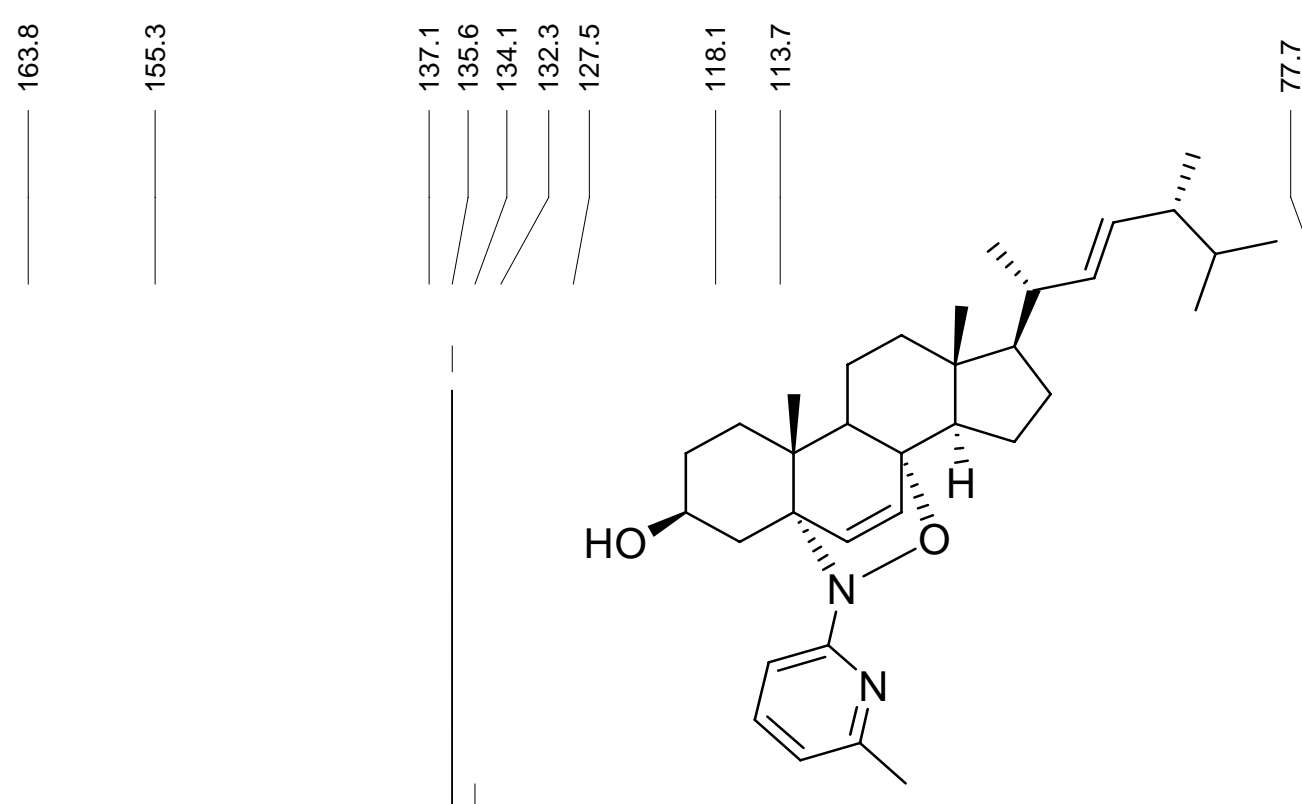

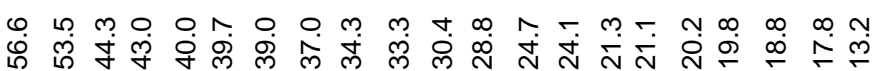

14

${ }^{13} \mathrm{C}$ NMR $\left(125 \mathrm{MHz}, \mathrm{CDCl}_{3}\right)$ 


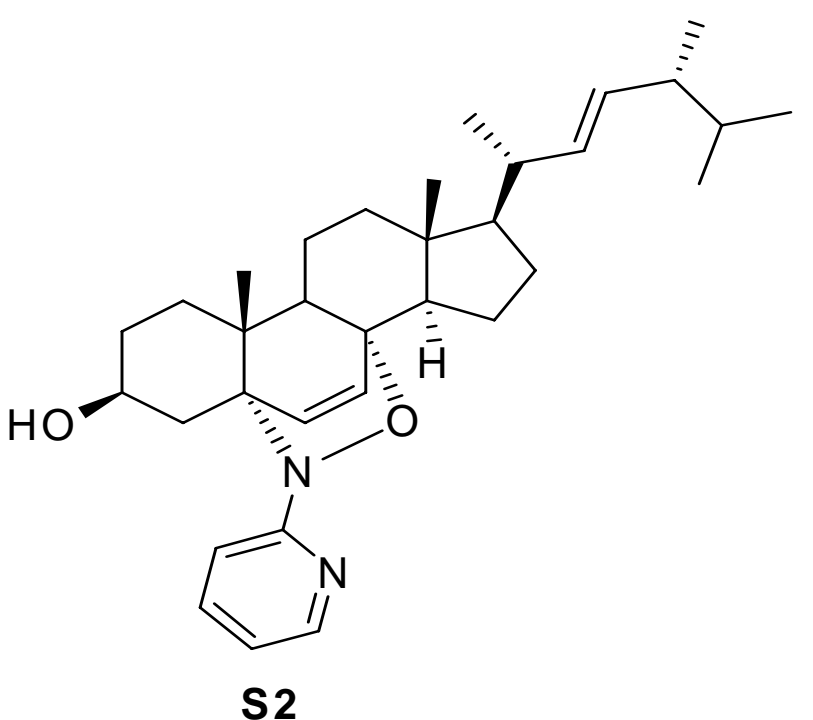

$\left({ }^{1} \mathrm{H} \mathrm{NMR}, 500 \mathrm{MHz}, \mathrm{CDCl}_{3}\right)$ 

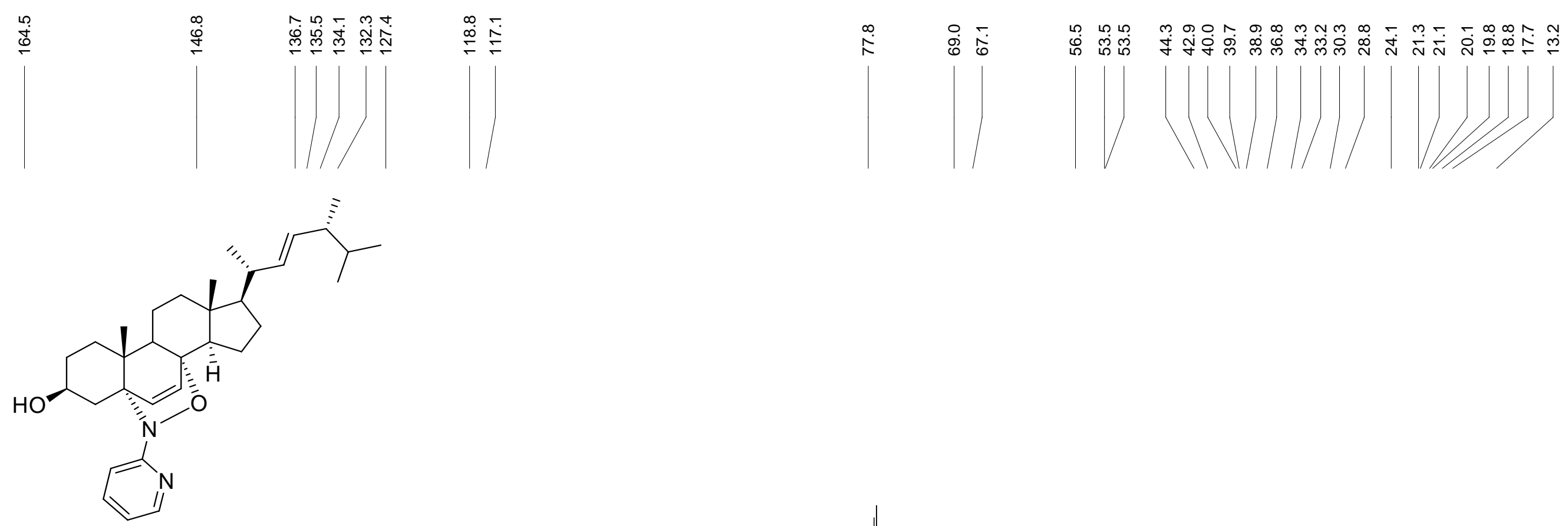

S2

$\left({ }^{13} \mathrm{C} \mathrm{NMR}, 125 \mathrm{MHz}, \mathrm{CDCl}_{3}\right)$

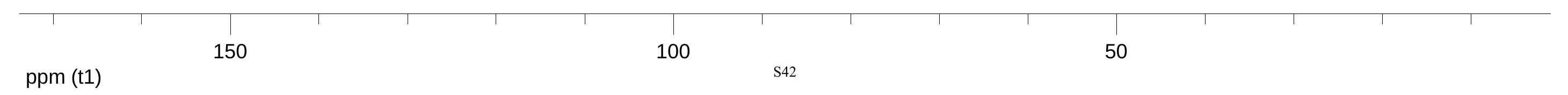




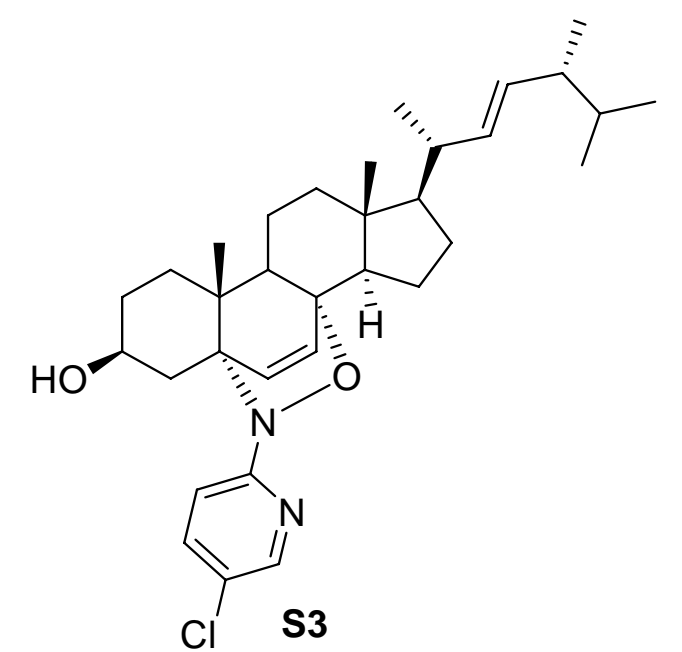

$\left({ }^{1} \mathrm{H} \mathrm{NMR}, 500 \mathrm{MHz}, \mathrm{CDCl}_{3}\right)$

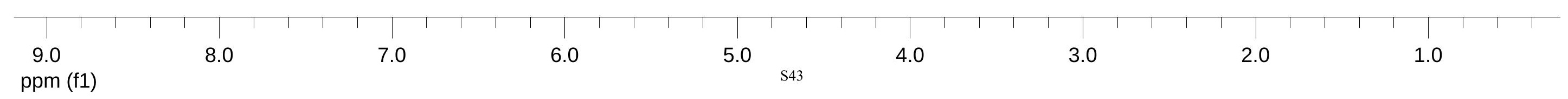




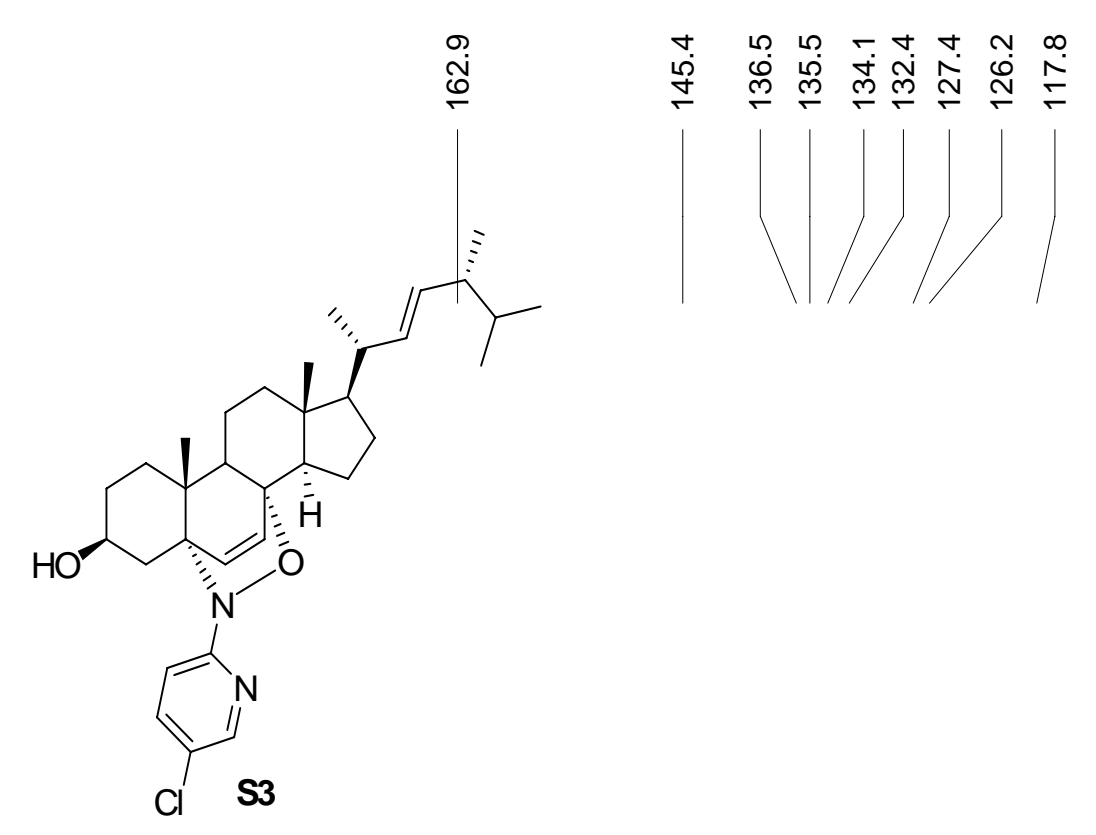

$\left({ }^{13} \mathrm{C} \mathrm{NMR}, 125 \mathrm{MHz}, \mathrm{CDCl}_{3}\right)$

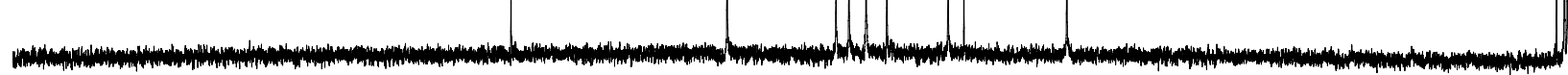




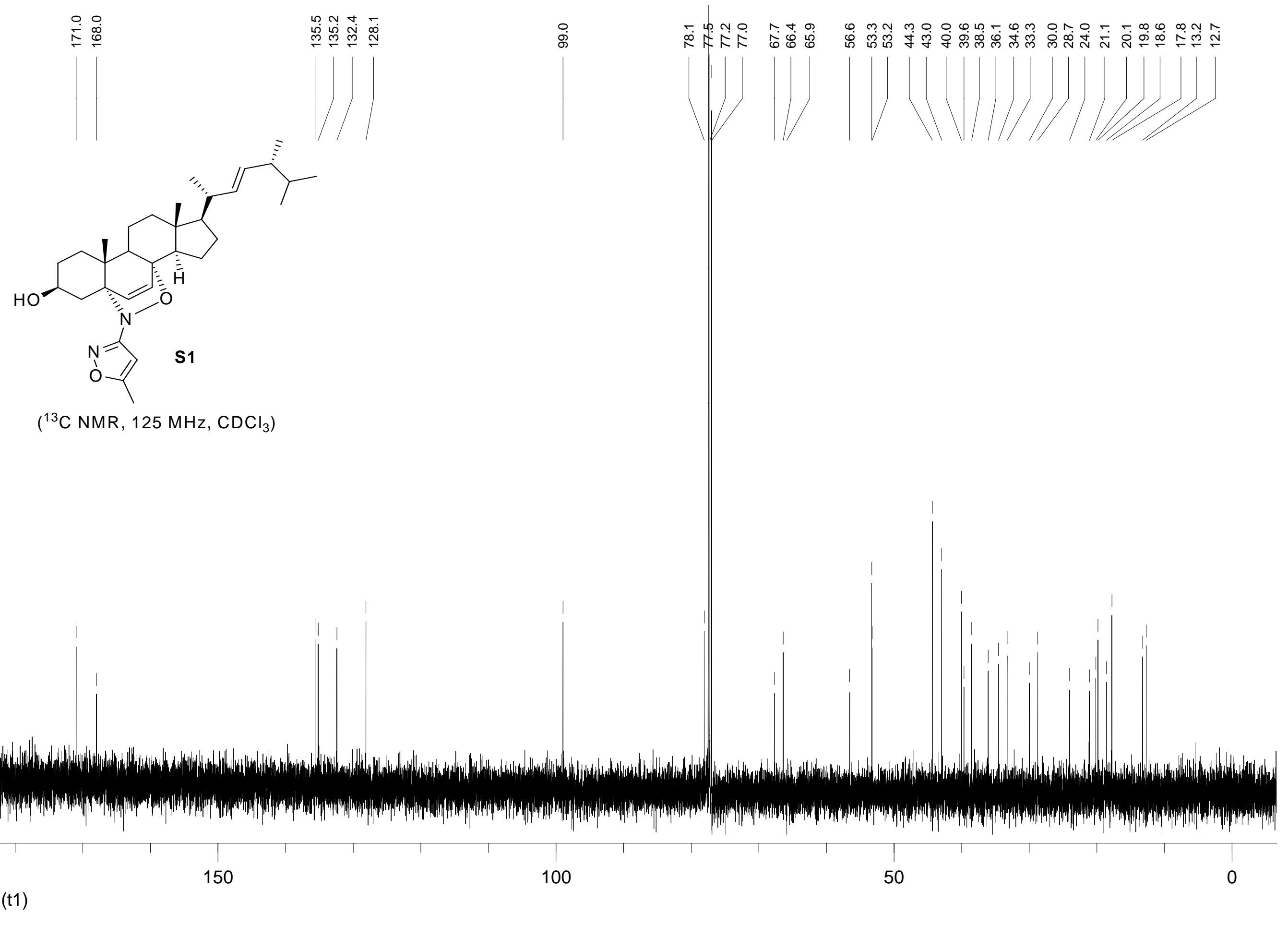




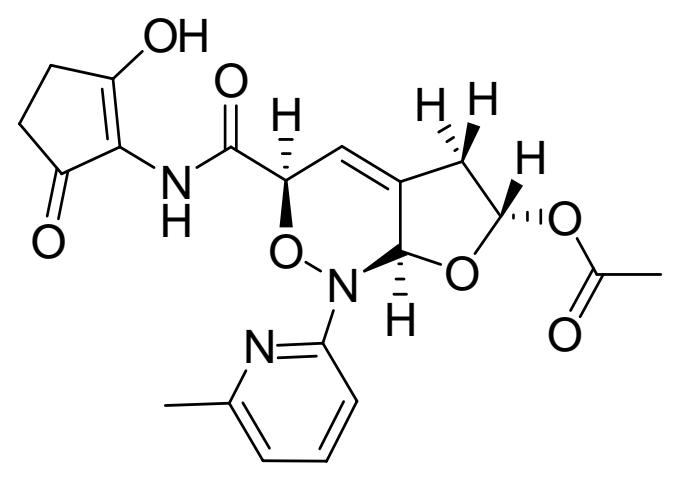

15

( ${ }^{1} \mathrm{H}$ NMR, $600 \mathrm{MHz}, \mathrm{CD}_{2} \mathrm{Cl}_{2}$ ) 


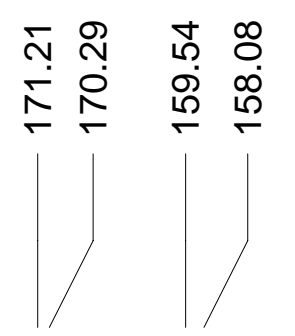

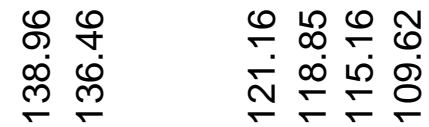

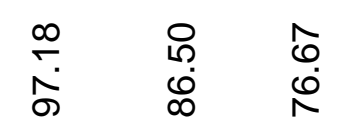

8
$\dot{+}$

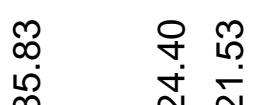

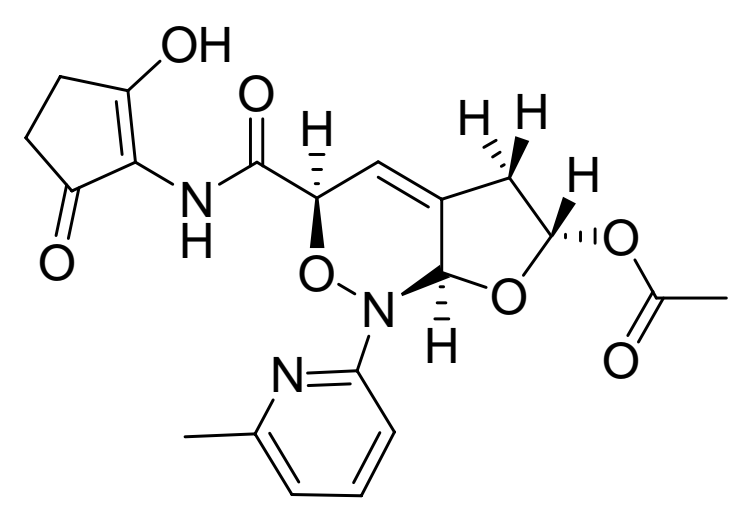

15

$\left({ }^{13} \mathrm{C}\right.$ NMR, $\left.150 \mathrm{MHz}, \mathrm{CD}_{2} \mathrm{Cl}_{2}\right)$

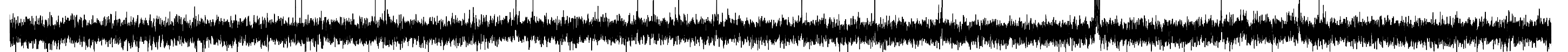

200

150

100

50 
(12

15

(2D-ROSEY, $600 \mathrm{MHz}, d_{8}$-THF)

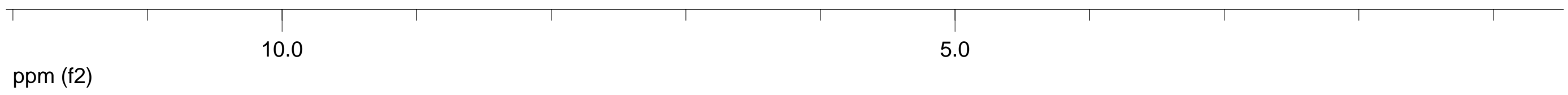




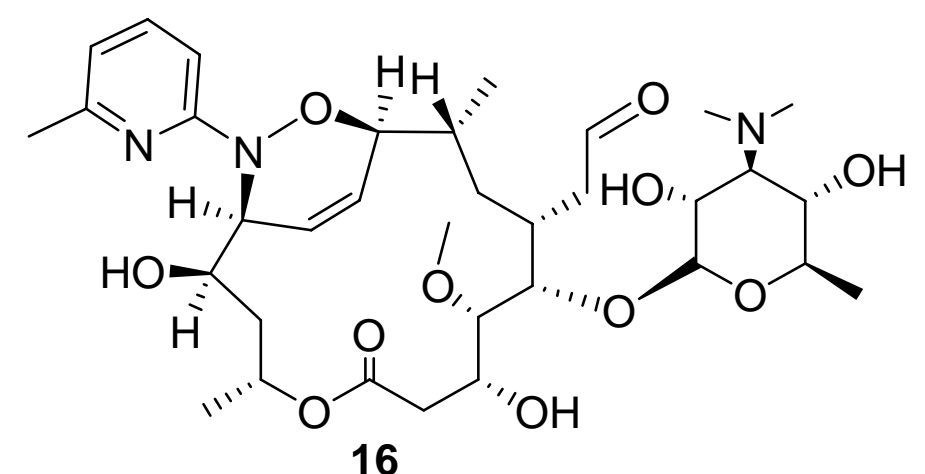

$\left({ }^{1} \mathrm{H}\right.$ NMR, $600 \mathrm{MHz}, \mathrm{CD}_{2} \mathrm{Cl}_{2}$ ) 


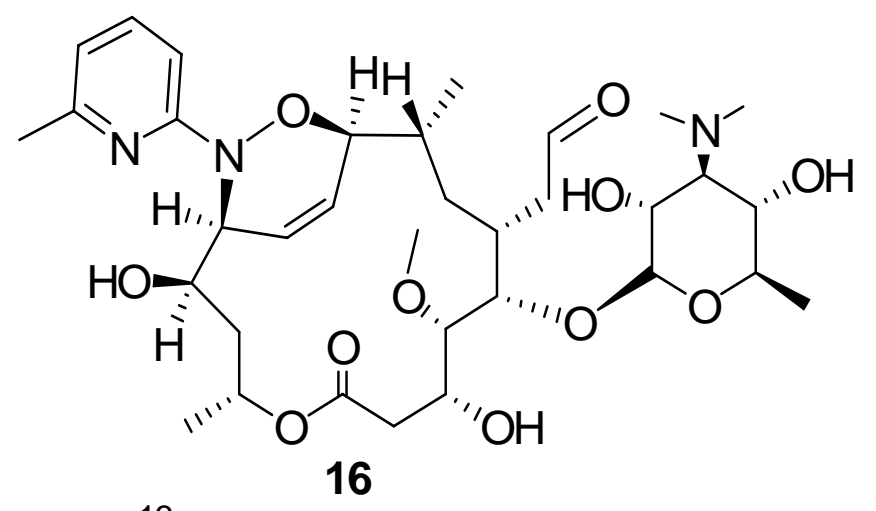

$\left({ }^{13} \mathrm{C} \mathrm{NMR}, 125 \mathrm{MHz}, \mathrm{CD}_{2} \mathrm{Cl}_{2}\right)$

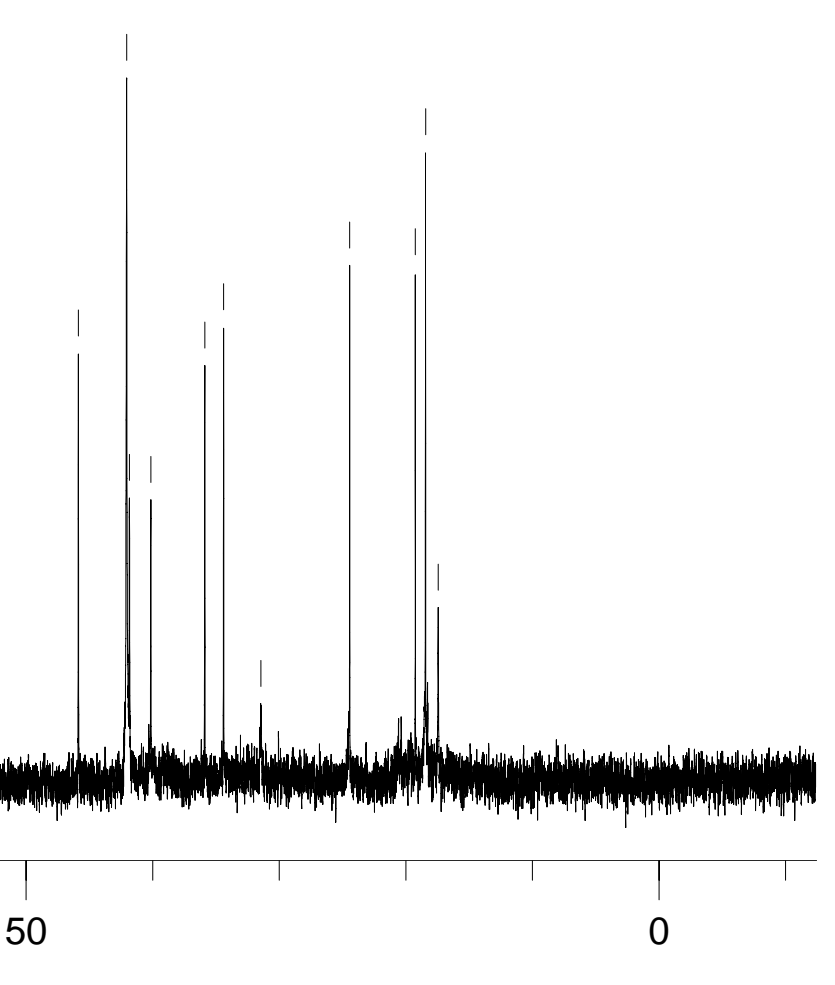




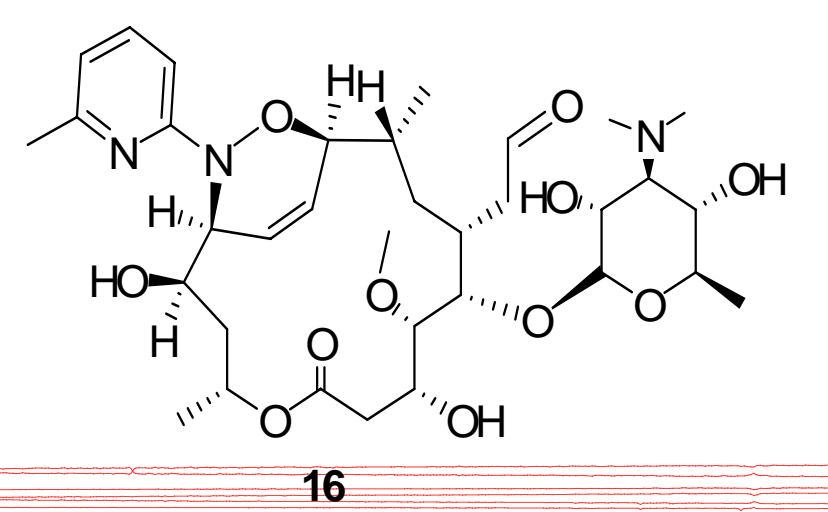

(2D-ROESY, $800 \mathrm{MHz}, d_{8}$-THF)

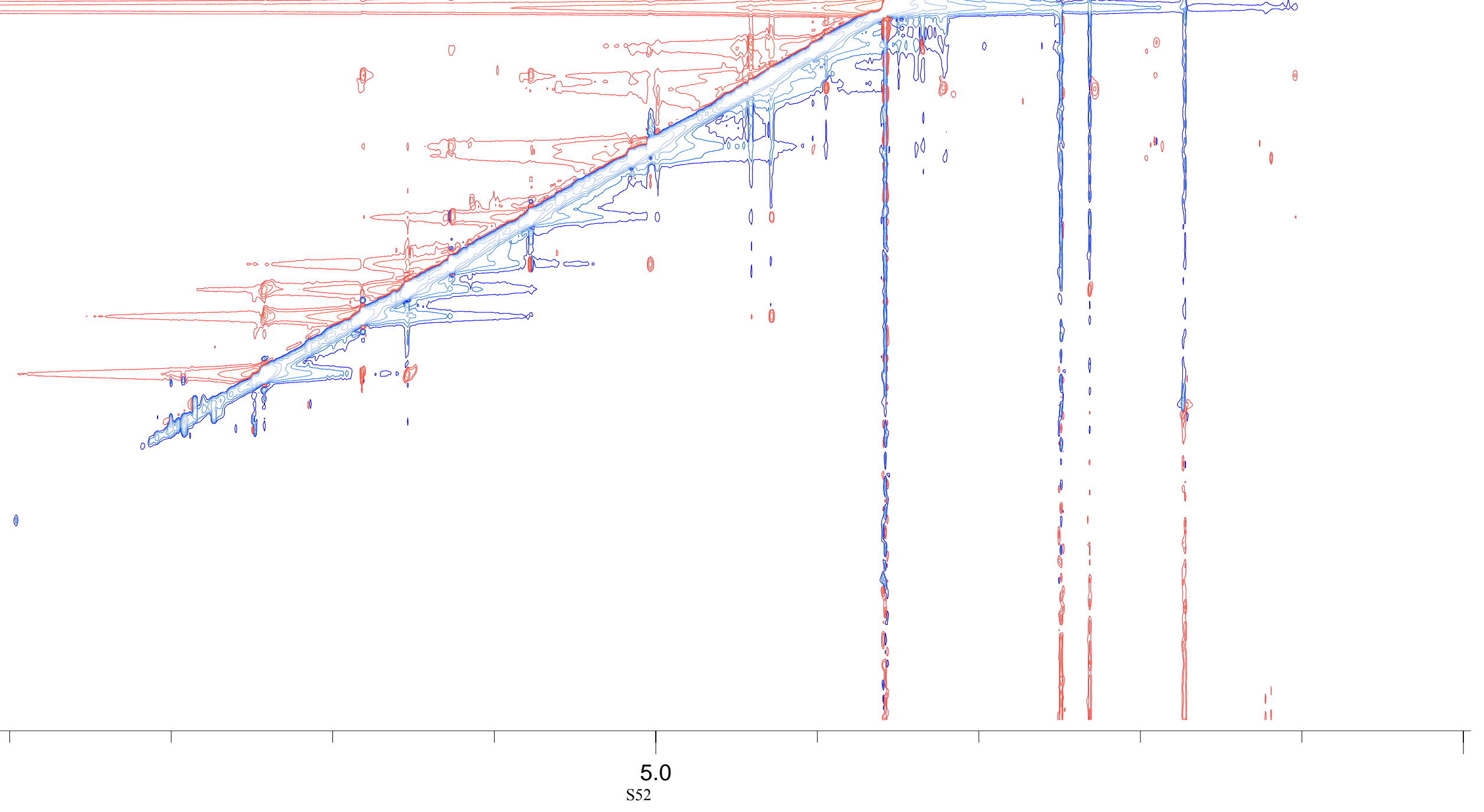




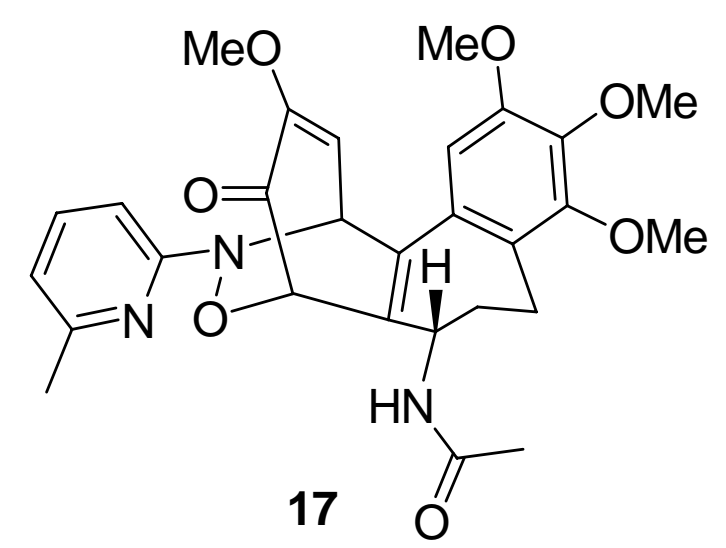

$\left({ }^{1} \mathrm{H} N M R, 300 \mathrm{MHz}, \mathrm{CD}_{3} \mathrm{OD}\right)$$$
9.0
$$
ppm (t1)
8.0

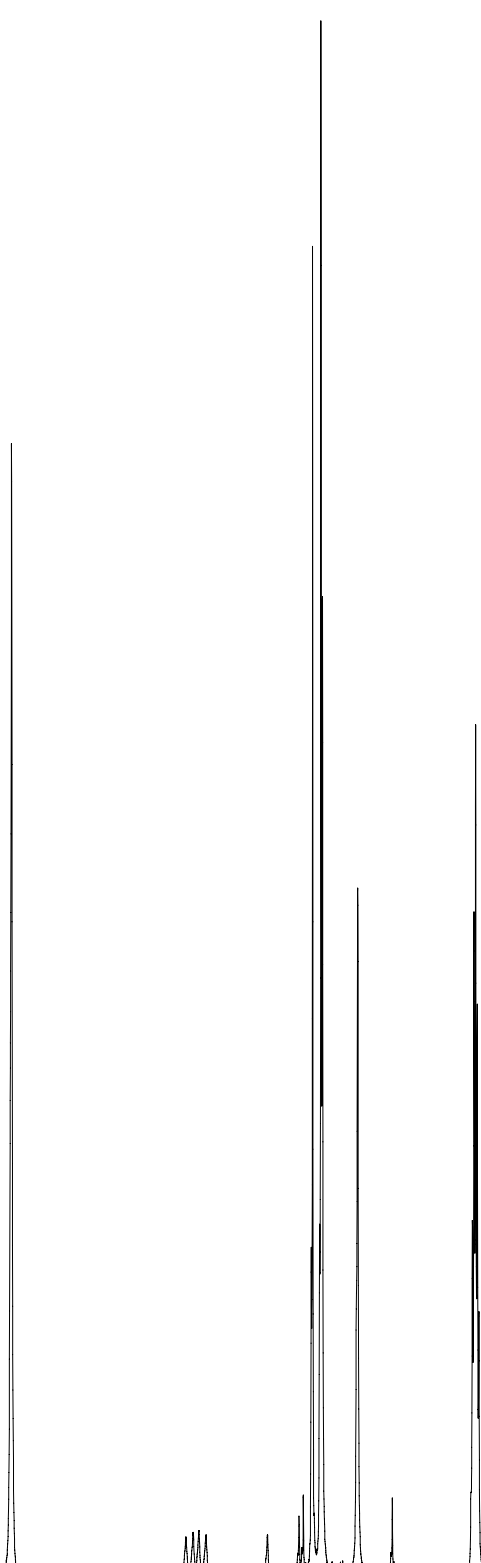




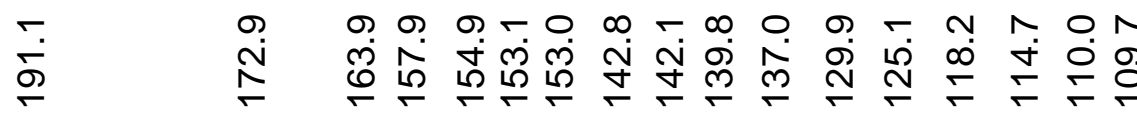

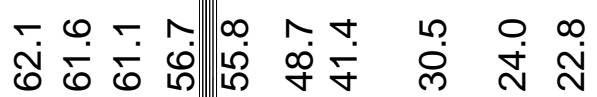
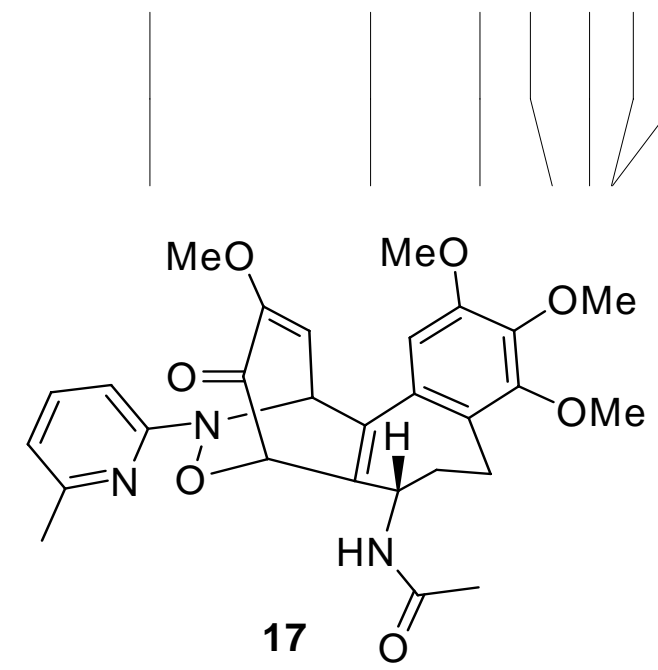

$\left({ }^{13} \mathrm{C} \mathrm{NMR}, 75 \mathrm{MHz}, \mathrm{CD}_{3} \mathrm{OD} / \mathrm{CDCl}_{3}\right)$

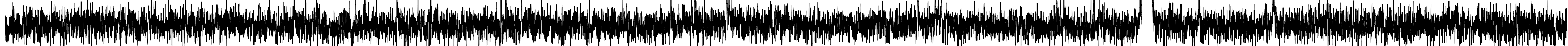

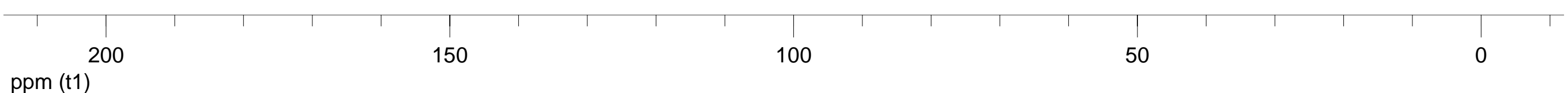




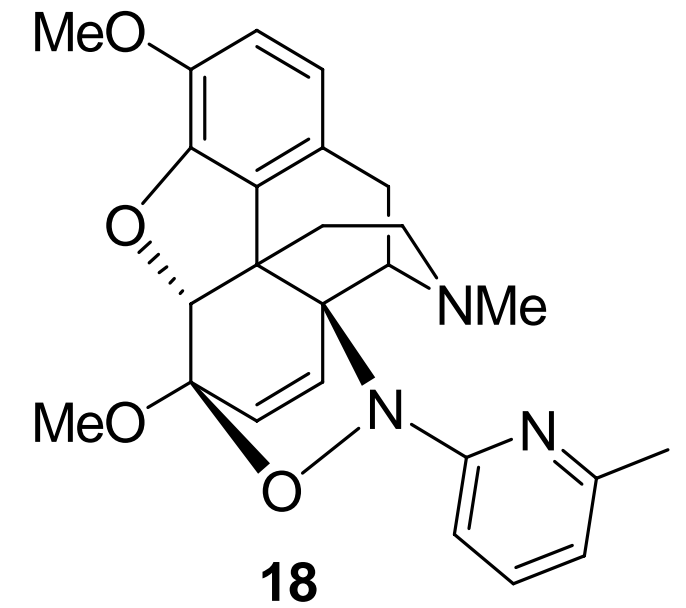

$\left({ }^{1} \mathrm{H} \mathrm{NMR}, 500 \mathrm{MHz}, \mathrm{CDCl}_{3}\right)$

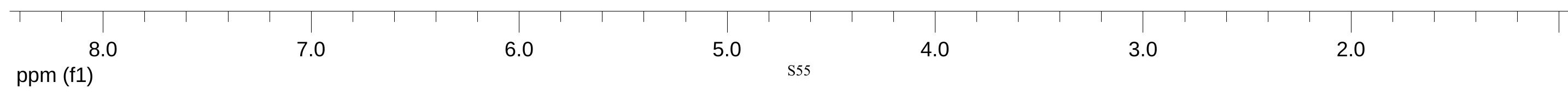



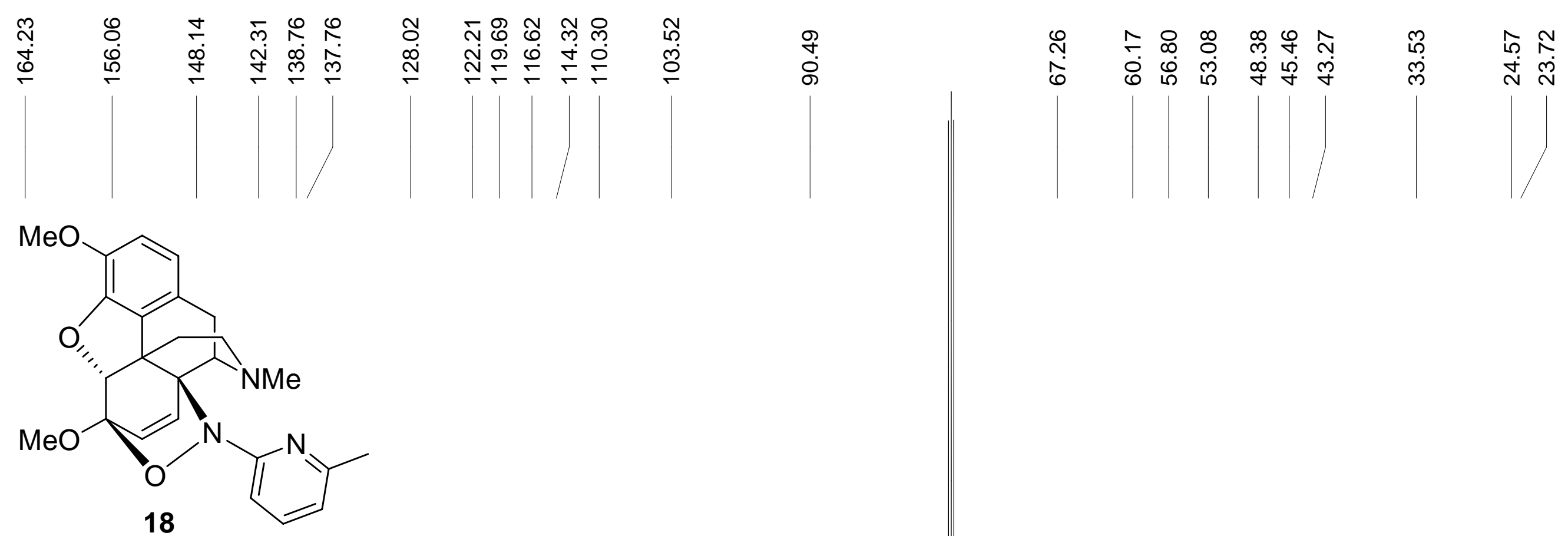

$\left({ }^{13} \mathrm{C} \mathrm{NMR}, 125 \mathrm{MHz}, \mathrm{CDCl}_{3}\right)$ 